\title{
A Large Goaf Group Treatment by means of Mine Backfill Technology
}

\author{
Hanwen Jia $\mathbb{D D}^{1,2}$ Baoxu Yan ${ }^{1}{ }^{3}$ and Erol Yilmaz ${ }^{4}{ }^{4}$ \\ ${ }^{1}$ Deep Mining Laboratory, Shandong Gold Group Co., Ltd., Yantai 264000, China \\ ${ }^{2}$ Center for Rock Instability and Seismicity Research, School of Resource and Civil Engineering, Northeastern University, \\ Shenyang 110819, China \\ ${ }^{3}$ Energy School, Xi'an University of Science and Technology, Xi'an 710054, China \\ ${ }^{4}$ Department of Civil Engineering, Geotechnical Division, Recep Tayyip Erdogan University, Fener, Rize TR53100, Turkey
}

Correspondence should be addressed to Baoxu Yan; yanbaoxu@xust.edu.cn

Received 11 September 2021; Revised 16 November 2021; Accepted 24 November 2021; Published 10 December 2021

Academic Editor: Qian Chen

Copyright (c) 2021 Hanwen Jia et al. This is an open access article distributed under the Creative Commons Attribution License, which permits unrestricted use, distribution, and reproduction in any medium, provided the original work is properly cited.

There are few studies on the management methods of large-scale goaf groups per the specific surrounding rock mass conditions of each goaf. This paper evaluates comprehensively the stability of the multistage large-scale goaf group in a $\mathrm{Pb}-\mathrm{Zn}$ mine in Inner Mongolia, China, via the modified Mathews stability diagram technique. The volume of each goaf to be backfilled was quantitatively analyzed in the combination of theoretical analysis and three-dimensional laser scanning technology. The corresponding mechanical characteristics of the filling were determined by laboratory testing while formulating the treatment scheme of the large goaf group using the backfill method. The applicability of the treatment scheme using the backfill was verified by the combination of the numerical results of the distribution of the surrounding rock failure zone and the monitored data of the surface subsidence. The research results and treatment scheme using the backfill can provide a reference for similar conditions of mines worldwide.

\section{Introduction}

The open stoping and shallow-hole blasting techniques have been most often employed in the initial steps of Chinese metal mining, bringing about the advance of the widely distributed goafs $[1,2]$. The existence of large goaf groups is a grave menace to the mines' safety. It is easy to cause a variety of mine disasters, such as roof caving [3], surface subsidence [4], rib failure [5], and water inrushing [6], resulting in irretrievable casualties and property losses [7]. The essence of the safety management of a large goaf group is to transfer the stress concentration, ease the stress concentration on the rock mass or make the stress state reach a new relative balance, and ensure the mines' pressure and their secure productions $[8,9]$.

There are several safety treatment methods for the mined-out area left by underground mining, and they are as follows: caving mined-out area, backfill mined-out area, and permanent pillar support mined-out area $[10,11]$. However, studies showed that the goaf treatment of caving surrounding the rock requires higher construction technology. A large number of rocks in the empty area are prone to a sudden fall and can cause airwave damage. Permanent pillars to support the goaf can only meet the needs of short-term stability. The roof of the goaf has the risk of instability failure under the conditions of engineering blasting disturbance and rheological properties of the rock [12]. Many researchers have made corresponding achievements in the treatment of goaf using the backfill method: Bao et al. [13] determined the grouting parameters and scheme based on the laboratory test and field measurement and completed the backfill treatment of underground goaf. Li et al. [14] used theoretical analysis to discuss the deformation mechanism of longwall goaf, studied the physical and chemical properties of backfill materials, and finally determined the grouting scheme to complete the treatment of longwall goaf. Zhang et al. [15] proposed the method of solid backfill for room and pillar mining method, which changed the stress transfer 
mechanism caused by secondary mining, in view of the great influence of secondary mining on the coal pillar in the process of mining by traditional caving method and chain instability failure of the coal pillar. Li et al. [16] studied whether backfill into the goaf has an influence on the rock strata movement and deformation of the surrounding rock mass, indicating that the cemented backfill has a great influence on the rock strata movement and can significantly slow down the surface subsidence and deformation, however, it cannot prevent surface subsidence. Kostecki and Spearing [17] showed that with the decrease of shear and unconfined compressive and tensile strength of the backfill, the coal pillar strength's increase was more owing to the limits of the mines instead of the material's mechanical properties.

However, thanks to the diverse conditions at each mine, each abandoned goaf provides information on different locations/morphological properties and treatment methods [18]. The stability of the mined-out area is a complex problem. It is not only related to the occurrence state of the mining body, such as buried depth, dip angle, and thickness but also related to the geological and mining conditions, such as mining times and mining methods [19-21].

The goaf stability analysis methods mainly include numerical simulation [22], in situ monitoring [23], and theoretical analysis [24]. For example, Qiao et al. [25] established the energy criterion of the underground space engineering stability using the catastrophe theory and evaluated the rock stability of a coal mine based on this criterion. Jiang et al. [26] predicted the deformation and failure depth of the surrounding rock of the underground chamber using the method of bionic particle swarm optimization combined with numerical calculation. Habibi et al. [27] assessed the durable stability of the diverse shapes and dimensions of the salt cavern subjected to cyclic loading based on numerical calculation. Yang et al. [28] evaluated the stability of underground cavities by combining the in situ stress monitoring data using the numerical simulation method.

Because of the idealization of theoretical formula construction and the limit of the sum of the field monitoring tools, the aforementioned method is inadequate for the stability evaluation of the large-scale multistage goaf group. It is worth noting that the Mathews stability graph method is a semiquantitative and semiempirical stope stability evaluation method [29]. The method is relatively simple and convenient for in situ implementation [30]. It can be used for stability evaluation before large-scale goaf management and is largely employed in underground hard-rock mining $[31,32]$.

In the process of backfilling and treating large minedout areas, it was generally adopted to treat all mined-out areas equally and adopt the same type of backfill, such as cemented backfill, ignoring the sequence of backfill. The differential conditions of the surrounding rock mass in each goaf were ignored. For example, local rock collapse occurred in some goaf, and the collapsed rock masses filled the bottom of the goaf. The filling effect of these collapsed rocks needs to be paid attention to in the process of goaf treatment. It is because the collapsed rock is often quite different from the cemented backfill in terms of mechanical properties. In addition, some of the mined-out area is relatively narrow and flat in spatial dimension, the surrounding rock deformation of this type of goaf is bigger after completing the backfill process, which will make the cemented backfill cause serious damage. Hence, at this time, it is not economic to use cemented backfill to treat the goaf. However, using uncemented backfill is often more effective and economic. That is to say, a precise backfill technique should be adopted when the large group goaf is treated.

This study evaluates comprehensively by the engineering background of a multistage large-scale goaf group in a Chinese $\mathrm{Pb}-\mathrm{Zn}$ mine using the modified Mathews stability diagram technique. The volume of each goaf to be backfilled was evaluated in combination with theoretical analysis and 3D laser scanning technology (CMS). The corresponding mechanical characteristics of the backfill were determined by a laboratory test. The treatment scheme of the large goaf group using the backfill method was also formulated. The applicability of the treatment scheme using the mine backfill technology was verified in combination with the numerical results of the distribution of the surrounding rock failure zone and the monitored data of surface subsidence.

\section{Engineering Background}

Figure 1 shows the areas on the east of the line form the "eastern district," and the areas on the west form the "western district" in the tested $\mathrm{Pb}-\mathrm{Zn}$ mine [33]. A geological model dealing the stope from a $768 \mathrm{~m}$ level to the $928 \mathrm{~m}$ level in the 3DMine software was established by field measurement and the existing engineering geological log. In the mining area, there are four surface subsidence areas and a total of six subsidence pits. The subsidence area of the F1 fracture zone of the lines 3 to $5,5526 \mathrm{~m}^{2}$ of the lines 9 to 13 , $16,237 \mathrm{~m}^{2}$ of the lines 25 to 29 , and $2100 \mathrm{~m}^{2}$ of the $\mathrm{F} 3$ fracture zone of the lines 53 to 57 is located in the delineated mobile zone as shown in Figure 1. The main reasons for the collapse are the goaf above the $808 \mathrm{~m}$ level in the western area, the oxidation of some ore bodies near the surface, broken surrounding rock on the hanging wall, the fact that the mining method is mostly the sublevel open stoping method of mid-hole caving, and a strong broken zone that is produced nearby.

\section{Stability Analysis of the Goaf Group}

3.1. Control Principle of Mathews Stability Diagram. Potvin [34] illustrates the stability diagram technique based on the calculation of HR (hydraulic radius) in the perilous surface and the improved stability no $\mathrm{N}^{\prime}$. These two factors were plotted on the graph and categorized as stable zone, transition zone, and caving zone (Figure 2) to express the stability of the underground excavation area $[34,35]$. The hydraulic radius HR in the stability graph can be obtained using equation (1). 


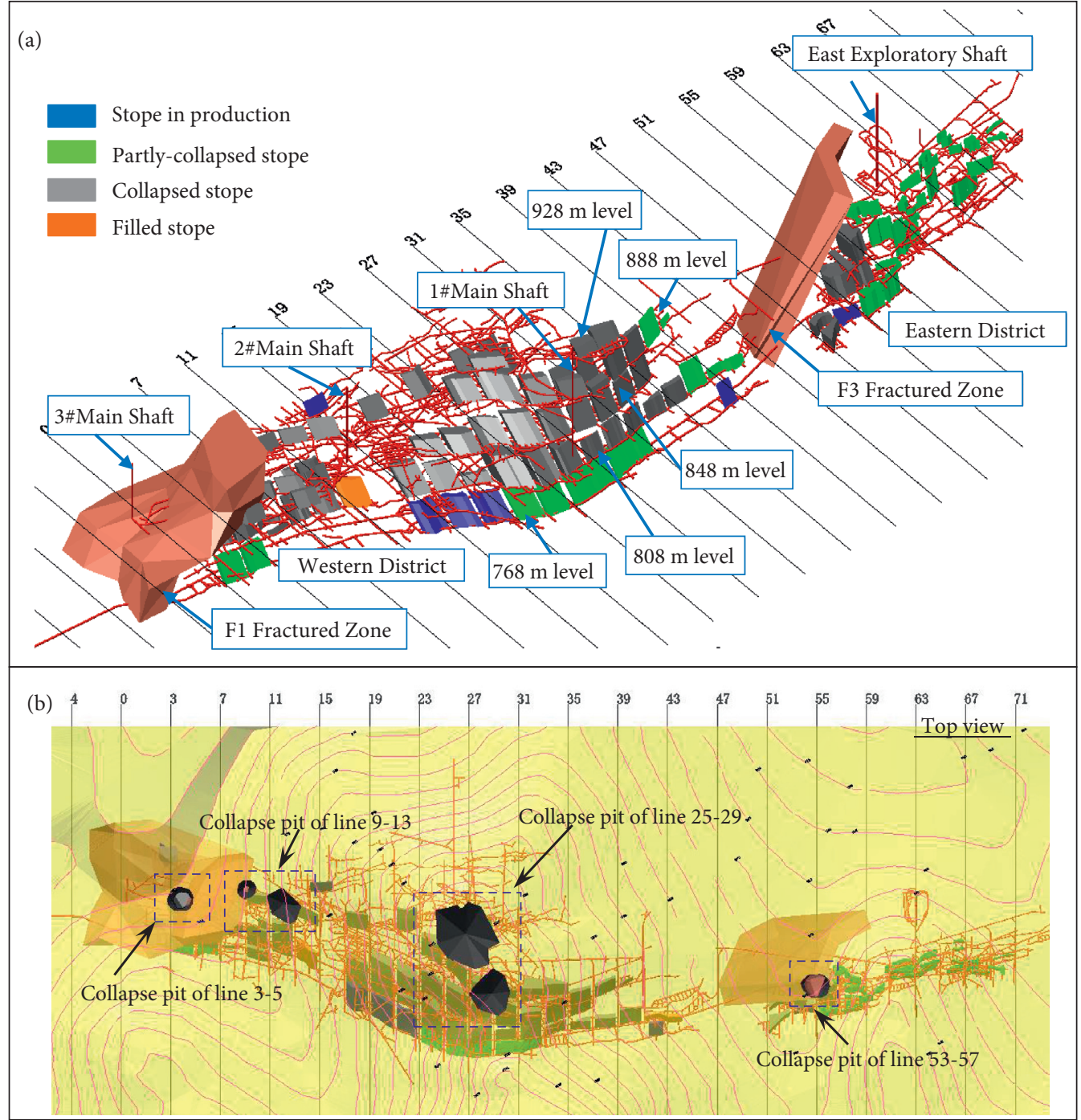

Figure 1: A layout of the tested $\mathrm{Pb}-\mathrm{Zn}$ mine [33] (a) and the top view of the surface collapse pit (b).

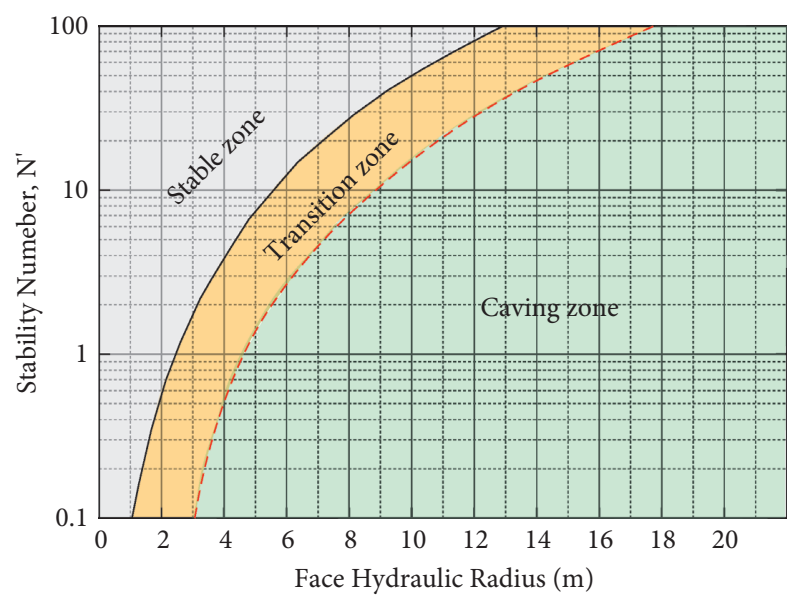

FIGURE 2: The Mathews stability graph [34].

$$
\mathrm{HR}=\frac{\text { length } \times \text { width }}{2 \times \text { length }+2 \times \text { width }} .
$$

The stability number $\mathrm{N}^{\prime}$ as shown in Figure 2 is calculated by equation (2).

$$
N^{\prime}=Q^{\prime} \times A \times B \times C,
$$

where $Q^{\prime}$ can be obtained by equation (3).

$$
\mathrm{Q}^{\prime}=\frac{\mathrm{RQD}}{J_{n}} \frac{J_{r}}{J_{a}},
$$

where RQD stands for rock quality index, $J_{\mathrm{n}}$ stands for joint number, $J_{\mathrm{r}}$ stands for joint roughness number, and $J_{\mathrm{a}}$ stands for joint change number.

Parameter B in equation (1) is the joint adjustment factor, and its value is measured by the difference between the dip angle of the mining face and the main joint set. Parameter $\mathrm{C}$ is the gravity adjustment factor. $\mathrm{A}$ is the rock stress factor. The compressive stress $\sigma_{1 \max }$ is the extreme induced tangential stress acting on the center of critical face. Parameter A is linearly related to UCS $/ \sigma_{1 \max }$, and its range is 0.1 to 1 . It is calculated by equations (4) and (5). The detailed 
procedure of these parameters can be found in the literature of Jia et al. [33].

$$
\begin{aligned}
& R=\frac{\mathrm{UCS}}{\sigma_{1 \max }}, \\
& A= \begin{cases}0.1, & \text { If } R<2, \\
\frac{0.9}{8}(R-2)+0.1, & \text { If } 2 \leq R \leq 10, \\
1, & \text { If } 10<R .\end{cases}
\end{aligned}
$$

For the rock materials, the tensile strength is much lower than the compressive strength, and hence, the instability caused by the tensile failure of rock mass must be estimated when calculating the modified stress coefficient, which is ignored by the current stability graph method [36]. Considering the influence of spatial multidimensional stress on the rock stress coefficient $A$, the authors modified the calculation method of the rock stress coefficient A by HoekBrown criterion, including tensile truncation [33]. The Mathews stability graph evaluation method suitable for thin orebody stope is obtained. This study will use this modified method to analyze the stability of the goaf group, providing a theoretical basis and reference for the subsequent goaf backfilling treatment planning.

\subsection{Stability Calculation of Goaf Based on Mathews Stability Graph}

3.2.1. Acquisition of Rock Parameters. In this paper, with the help of the ShapeMetrix3D digital measurement system, the rock mass discontinuities of 10 stopes in the eastern and western areas are investigated in a targeted way. As shown in Figure 3, the rock mass discontinuities are synthesized according to the obtained images based on similar pixel matching and line-of-sight judgment techniques. The mean value of the digital measurement results was taken to acquire the information of rock mass joints and the fissures and joints of each stope, and the results are listed in Table 1.

In this study, the rock mass geomechanical RMR value is converted into Barton's Q value using the basic rock mass quality index BQ value, the empirical conversion formula of the rock mass geomechanical RMR value [37], the Barton rock mass quality $\mathrm{Q}$ value given by Barton considering joint orientation, and the rock mass geomechanical RMR value [38]. Then, the Barton-modified $\mathrm{Q}^{\prime \prime}$ value of the rock mass was solved. The joint density of Alhada rock mass $J_{\mathrm{v}}=7.23$ strip $/ \mathrm{m}^{3}$ per $3 \mathrm{GSM}$ sweeps surface. Considering the surface conditions and joint density values, the geological strength index (GSI) of the rock mass is 60 per the rock mass structure. The main rock type of Alhada lead-zinc deposit is the argillaceous slate, and the material constant $m_{\mathrm{i}}=10 \mathrm{can}$ be obtained. As inferred from the above data, the rock mass strength variables of the orebody and the surrounding rock can be obtained (Table 2), which provides a basis for numerical simulation and solving the rock stress coefficient A.

$$
\begin{aligned}
& \mathrm{RMR}=15 \ln Q+50, \\
& \mathrm{RMR}=\frac{(B Q-80.79)}{6.09} .
\end{aligned}
$$

\subsubsection{The Determination of Stability Number $N$ and Hydraulic} Radius HR. The rock stress coefficient calculation method proposed by Jia et al. [33] requires a numerical simulation to obtain the highest and lowest principal stresses $\left(\sigma_{1}\right.$ and $\sigma_{3}$, respectively) in the center of the stope's critical face. This study uses the FLAC ${ }^{3 \mathrm{D}}$ and Rhino software to build numerical models. The model boundary dimensions are as follows: the length of $2400 \mathrm{~m}$, the width of $600 \mathrm{~m}$, and the average height of approximately $400 \mathrm{~m}$. The top surface varies with the height of surface fluctuation: the highest height is $449 \mathrm{~m}$, and the lowest height is $370 \mathrm{~m}$. Figure 4 shows the numerical model. In the model's calculation, only the gravity stress field is considered, i.e., the equilibrium is solved only under the action of the self-weight of the rock. The boundary condition is that the top of the model is a free surface. The horizontal and vertical displacement limits are levied on the nearby boundary and the bottom, respectively.

The mechanical parameters of numerical calculation were selected according to Table 2. The Mohr-Coulomb constitutive model was adopted to excavate the mining rooms one by one in accordance with the actual mining sequence of the mine. The rock stress coefficients of each stope roof from the $808 \mathrm{~m}$ to $888 \mathrm{~m}$ stage were calculated per the contours of the mining-induced Max. principal stress and Min. principal stress shown in Figure 5.

For the value of $\mathrm{B}$, the included angle between the exposed stope surface in the stereographic projection and the main joints in Table 1 are used for calculation, and parameter $\mathrm{B}$ is obtained according to the diagram of $\mathrm{B}$ in literature [34]. The value of $\mathrm{C}$ is mainly determined by $C=8$ $6 \cos \alpha$. Hydraulic radius $\mathrm{HR}$ is calculated according to geometric parameters of each stope. According to the roof stability number $\mathrm{N}$ and hydraulic radius $\mathrm{HR}$ of each goaf calculated above, the Mathews stability graph of each goafs roof in the middle stage of $888 \mathrm{~m}, 848 \mathrm{~m}$, and $808 \mathrm{~m}$ is finally obtained as shown in Figure 6. The stability evaluation results of each stope are shown in Tables 3, 4, 5. According to the field survey and calculation results, a three-dimensional model of the stope stability is drawn in Figure 7. At this point, the stope can be divided into a collapsed stope in the caving zone, a collapsed stope in the transition zone, a partly-collapsed stope in the stable zone, a partly-collapsed stope in the transition zone, a stope in production, and a filled stope. During the treatment of goaf, more attention will be paid to the first backfilling areas of the partly-collapsed stope in the stable zone and the partly-collapsed stope 


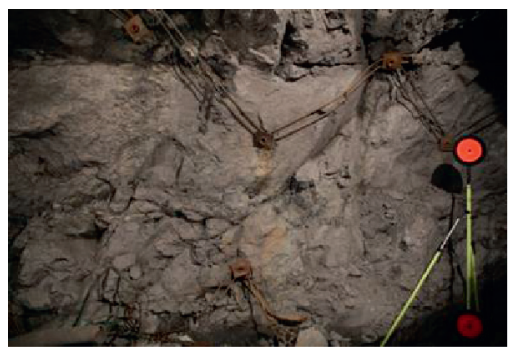

(a)

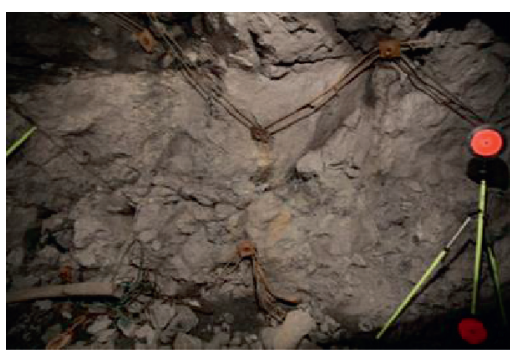

(b)

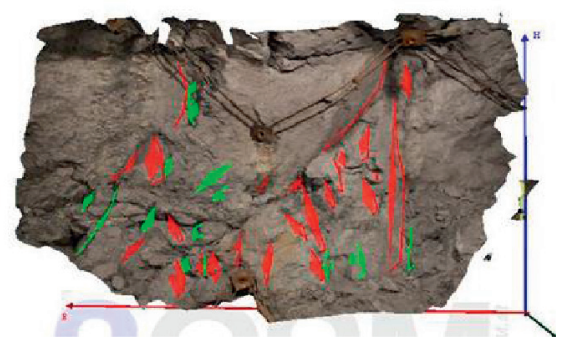

(c)

Figure 3: The scanning map of rock mass structural plane. (a) left view; (b) right view; (c) synthetic 3D map [33].

TABLE 1: The stope structural information.

\begin{tabular}{lc}
\hline Main joint tendency $\left({ }^{\circ}\right)$ & Main joint dip $\left(^{\circ}\right)$ \\
\hline 120 & 81 \\
85 & 71 \\
47 & 64 \\
213 & 67 \\
332 & 58 \\
314 & 32 \\
251 & 66 \\
297 & 44 \\
161 & 81 \\
236 & 38 \\
\hline
\end{tabular}

TABLE 2: Rock mass mechanical variables.

\begin{tabular}{lcc}
\hline Variables & Slate & Ore \\
\hline Uniaxial compressive strength $(\mathrm{MPa})$ & 9.38 & 7.65 \\
Uniaxial tensile strength $(\mathrm{MPa})$ & 0.61 & 0.68 \\
Apparent cohesion $(\mathrm{MPa})$ & 2.28 & 2.11 \\
Angle of friction $\left(^{\circ}\right)$ & 34.87 & 32.74 \\
Young's modulus $(\mathrm{GPa})$ & 13.65 & 10.95 \\
Specific gravity & 2.58 & 3.67 \\
Poisson's ratio & 0.31 & 0.18 \\
\hline
\end{tabular}

in the transition zone. The stability evaluation results provide a theoretical basis for the further formulation of a goaf backfilling planning.

\subsection{Estimation of Goaf Volume Based on CMS Detection.} The goaf is the structure left over after mining the orebody, and hence, it has the same structure and similar spatial morphology as the orebody. The mined-out areas left by the same vein keep a high degree of self-similarity in spatial morphology. Thus, the occurrence of other mined-out areas in the same vein can be qualitatively analyzed according to the detected mined-out area morphology, caving height, and stable state. In this paper, the cavity monitoring system (CMS) developed by Optech in Canada is used to conduct the spatial detection of the goaf of a typical stope.

Because of the open-pit operation in Alhada lead-zinc mine, most of the remaining mined-out areas have been damaged. Restricted by the site conditions, the stopes 7635 of the $35^{\text {th }}$ line in the western area and 7661 of the $61^{\text {st }}$ line in the eastern area are selected as reference stopes to distinguish the occurrence state of the mined-out areas. The stope span of 7635 is $100 \mathrm{~m}$ with an inclination angle of $42^{\circ}$. The stope of 7661 has a $63 \mathrm{~m}$ span and $68^{\circ}$ dip angle. The two stopes have the largest span and a slow dip angle on the west and east, respectively, and have the necessary conditions as a reference stope. Figure 8 indicates the caving conditions of the mined-out areas in stopes 7635 and 7661 .

The stope span of 7635 is large, and the CMS laser scanner has a scanning blind area. Hence, the scanning results fail to cover all the stopes of 7635. It is observed from Figure 8 (a) that the caving height is $14-17.5 \mathrm{~m}$. Figure $8(\mathrm{~b})$ shows that the caving height of stope 7661 is $8.2 \mathrm{~m}$ to $13.6 \mathrm{~m}$. According to the field survey of the $888 \mathrm{~m}$ to $808 \mathrm{~m}$ stage in the west area, the stope is almost collapsed. Based on CMS laser detection, it can be seen that the final collapse form of 7635 stope in the western area is caused by the instability of the stope hang wall, and the stope roof is well-preserved. Therefore, it can be inferred that the $57^{\text {th }}$ goaf collapsed from the stage of $888 \mathrm{~m}$ level to the stage of $808 \mathrm{~m}$ level in the western area is not caved in, and there may be triangular mined-out areas in the roof as shown in Figure 9.

The shape of the triangular mined-out area is determined by the static natural repose angle of rock, which is $40^{\circ}$ in the lead-zinc mine. Therefore, it can be estimated that the residual mined-out area volume of 57 stopes collapsed in the west area accounts for about $5.8 \%$ of the stope volume. As the backfilling method is used for mining below the $808 \mathrm{~m}$ level, the goaf in the $768 \mathrm{~m}$ level in the western area is relatively well-preserved. It can be seen from the above section that the average height of the caved bulk in 7635 stope is approximately $15.7 \mathrm{~m}$. From the ratio of the caved bulk height to the stope design height, it can be roughly concluded that the residual goaf volume in the west stope of $768 \mathrm{~m}$ level accounts for $50.9 \%$ of the stope volume.

According to the field survey on the $888 \mathrm{~m}$ level to $768 \mathrm{~m}$ level in the eastern district, except for the collapse of 7 stopes near the broken zone of lines 43 to 51, the mined-out areas of the other 28 stopes are relatively well-preserved. According to CMS laser detection results, the average caving height of the bulk in 7661 stope is approximately $10.9 \mathrm{~m}$. From the ratio of the caving bulk height to the stope design height, it can be roughly concluded that the residual cavity volume in the eastern stope accounts for $65.9 \%$ of the stope volume. Similarly, there may still be triangular mined-out areas in the 


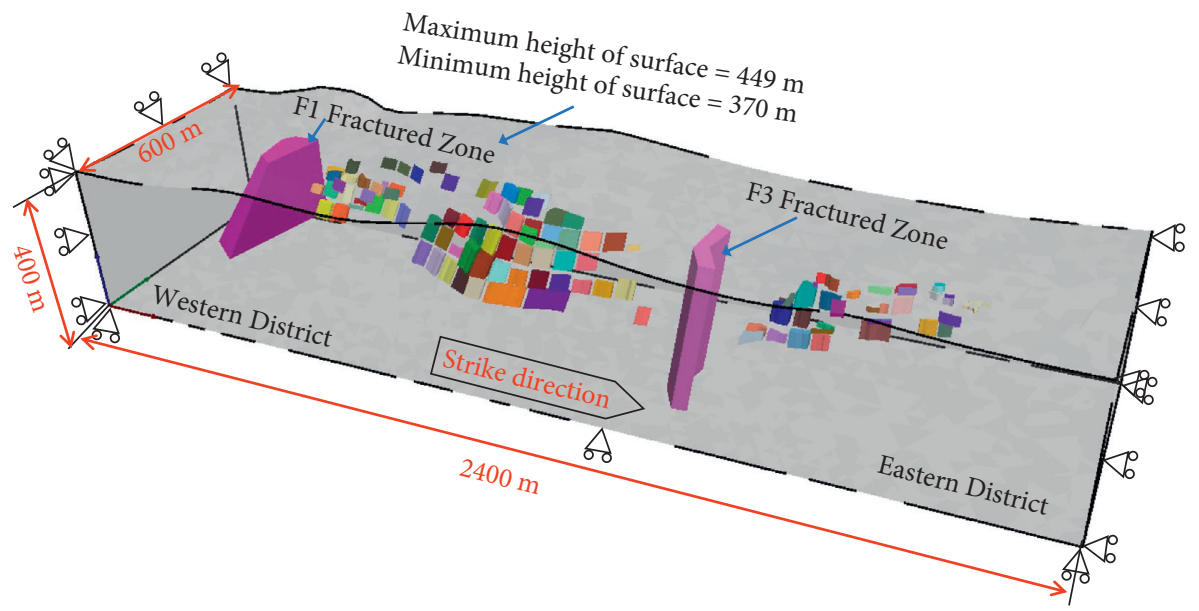

Figure 4: Numerical model.

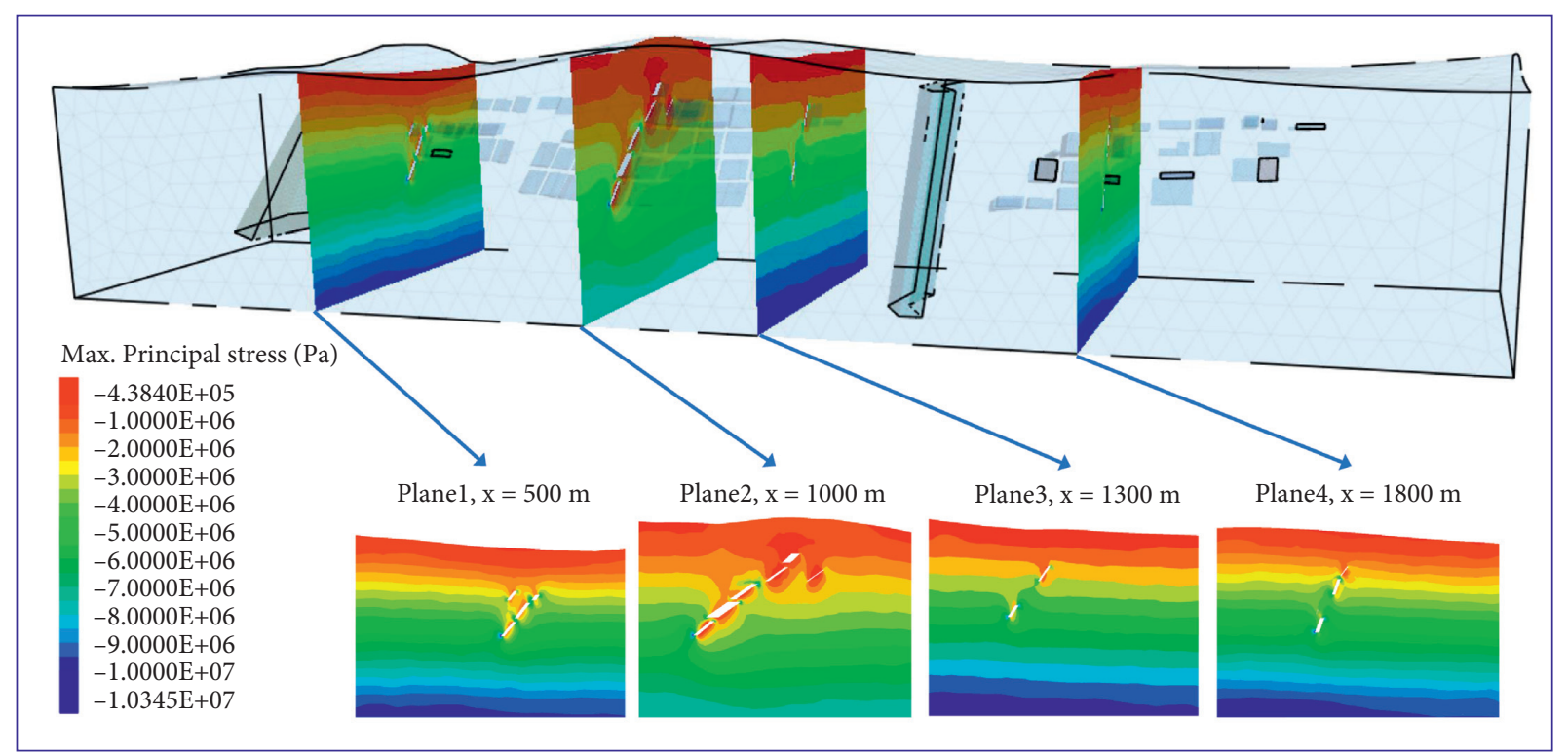

(a)

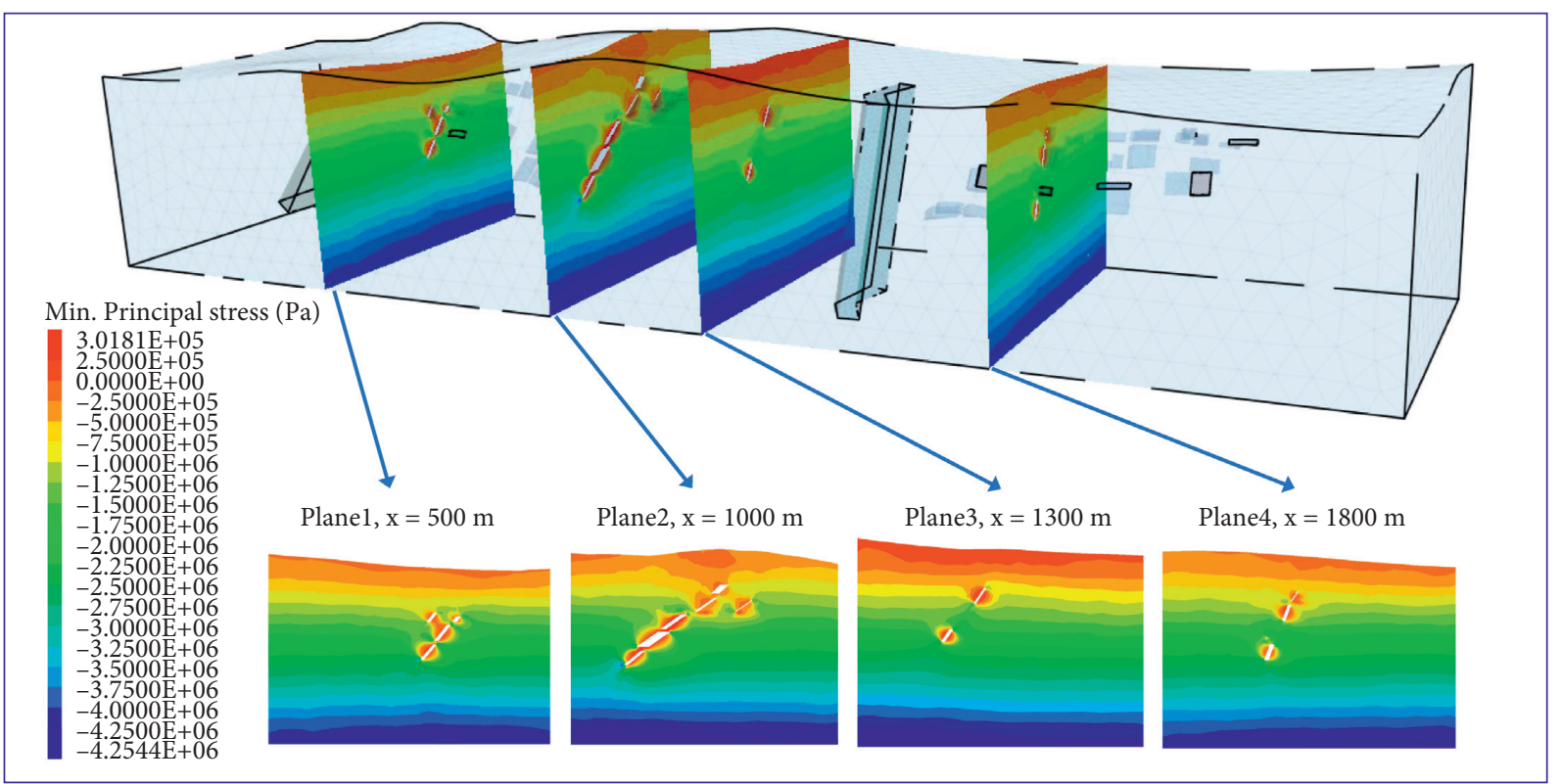

(b)

FIgURE 5: Contours of mining-induced (a) Max. principal stress and (b) Min. principal stress. 


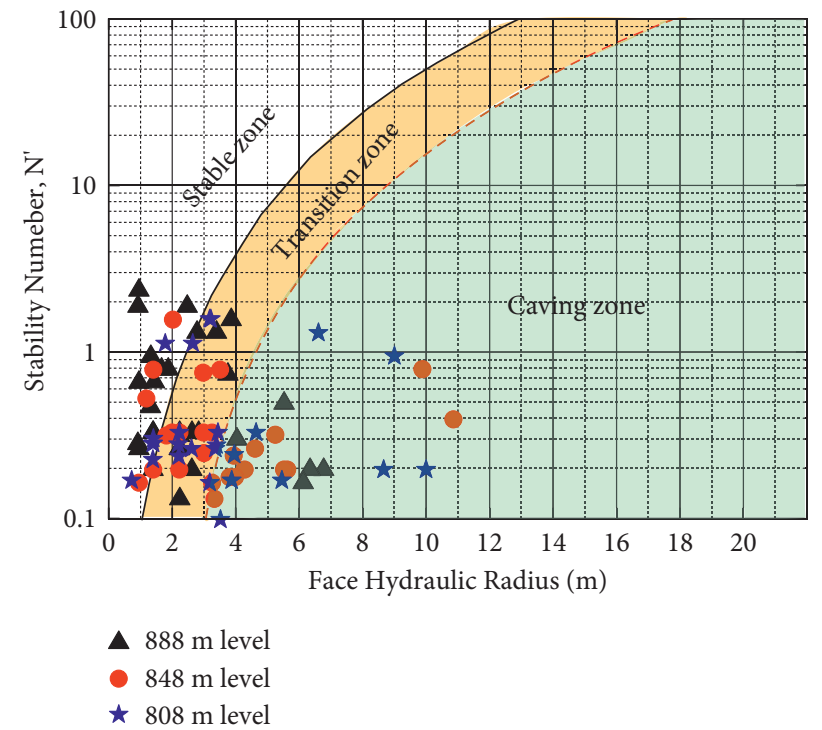

Figure 6: Mathews stability graph.

TABLE 3: Statistical results of goaf volume in $808 \mathrm{~m}$ level.

\begin{tabular}{|c|c|c|c|c|c|c|c|c|}
\hline $\begin{array}{l}\text { Stop } \\
\text { number }\end{array}$ & $\begin{array}{c}\text { Stope } \\
\text { position }\end{array}$ & $\begin{array}{c}\text { Stope } \\
\operatorname{span}(\mathrm{m})\end{array}$ & $\begin{array}{c}\text { Stope } \\
\text { height }(\mathrm{m})\end{array}$ & $\begin{array}{c}\text { Stope } \\
\text { thickness (m) }\end{array}$ & $\begin{array}{l}\text { Exposed area of } \\
\text { roof }\left(\mathrm{m}^{2}\right)\end{array}$ & $\begin{array}{c}\text { Exposed } \\
\text { perimeter of roof } \\
(\mathrm{m})\end{array}$ & $\begin{array}{l}\text { Goaf volume } \\
\qquad\left(\mathrm{m}^{3}\right)\end{array}$ & $\begin{array}{l}\text { Results of stability } \\
\text { graph method }\end{array}$ \\
\hline $808-1 \#$ & $1-3$ line & 20 & 15 & 10.5 & 210 & 61 & 260.8 & Transition zone \\
\hline $808-2 \#$ & 3-5 line & 41 & 34 & 9.8 & 401.8 & 101.6 & 638.6 & Transition zone \\
\hline 808-3\# & $5-7$ line & 42 & 34 & 9.5 & 399 & 103 & 646.2 & Transition zone \\
\hline $808-4 \#$ & 7-9 line & 41 & 10 & 1.5 & 61.5 & 85 & 78.1 & Stable zone \\
\hline $808-5 \#$ & 9-11 line & 41 & 34 & 8.5 & 348.5 & 99 & 569.5 & Transition zone \\
\hline $808-6 \#$ & 11-13 line & 42 & 34 & 8 & 336 & 100 & 557.1 & Transition zone \\
\hline $808-7 \#$ & 13-15 line & 42 & 34 & 7.5 & 315 & 99 & 557.6 & Transition zone \\
\hline $808-8 \#$ & 17-19 line & 41 & 34 & 12 & 492 & 106 & Backfilled & Caving zone \\
\hline 808-9\# & 19-21 line & 40 & 30 & 5 & 200 & 90 & 327.5 & Transition zone \\
\hline 808-10\# & 21-23 line & 40 & 12 & 6 & 240 & 92 & 253.5 & Transition zone \\
\hline $808-11 \#$ & 23-25 line & 40 & 34 & 40 & 1600 & 160 & 3813.3 & Caving zone \\
\hline $808-12 \#$ & 25-27 line & 41 & 34 & 30 & 1230 & 142 & 2521.4 & Caving zone \\
\hline 808-13\# & 27-29 line & 40 & 30 & 15 & 600 & 110 & 709.8 & Caving zone \\
\hline $808-14 \#$ & 29-31 line & 38 & 25 & 3 & 114 & 82 & 76.0 & Transition zone \\
\hline 808-15\# & 31-33 line & 39 & 27 & 3 & 117 & 84 & 215.8 & Transition zone \\
\hline $808-16 \#$ & 31-35 line & 40 & 27 & 3 & 120 & 86 & 193.5 & Transition zone \\
\hline $808-17 \#$ & 35-37 line & 40 & 22 & 3 & 120 & 86 & 319.7 & Transition zone \\
\hline 808-18\# & 37-39 line & 38 & 27 & 5 & 190 & 86 & 593.4 & Transition zone \\
\hline 808-19\# & 39-41 line & 35 & 34 & 5 & 175 & 80 & 365.9 & Transition zone \\
\hline $808-20 \#$ & 41-45 line & 45 & 12 & 8 & 360 & 106 & Backfilled & Transition zone \\
\hline $808-21 \#$ & 53-55 line & 45 & 30 & 30 & 1350 & 150 & 1827.3 & Caving zone \\
\hline $808-22 \#$ & 55-57 line & 39 & 30 & 20 & 780 & 118 & 1066.0 & Caving zone \\
\hline $808-23 \#$ & 57-59 line & 45.1 & 8 & 7.5 & 338.25 & 105.2 & 1523.0 & Transition zone \\
\hline $808-24 \#$ & 57-59 line & 42 & 8 & 7.5 & 315 & 99 & 335.4 & Transition zone \\
\hline $808-25 \#$ & $61-63$ line & 46 & 8 & 3 & 138 & 98 & 1162.2 & Transition zone \\
\hline $808-26 \#$ & 61-63 line & 46 & 8 & 3 & 138 & 98 & 1097.2 & Transition zone \\
\hline $808-27 \#$ & $65-67$ line & 45.5 & 34 & 6 & 273 & 103 & 3408.0 & Transition zone \\
\hline $808-28 \#$ & 67-69 line & 32.4 & 34 & 4 & 129.6 & 72.8 & 2113.8 & Stable zone \\
\hline Total & & & & & 25230.6 & & & \\
\hline
\end{tabular}


TABLE 4: Statistical results of goaf volume in $848 \mathrm{~m}$ level.

\begin{tabular}{|c|c|c|c|c|c|c|c|c|}
\hline $\begin{array}{l}\text { Stop } \\
\text { number }\end{array}$ & $\begin{array}{c}\text { Stope } \\
\text { position }\end{array}$ & $\begin{array}{c}\text { Stope } \\
\operatorname{span}(\mathrm{m})\end{array}$ & $\begin{array}{c}\text { Stope } \\
\text { height }(\mathrm{m})\end{array}$ & $\begin{array}{c}\text { Stope } \\
\text { thickness }(\mathrm{m})\end{array}$ & $\begin{array}{c}\text { Exposed area of } \\
\text { roof }\left(\mathrm{m}^{2}\right)\end{array}$ & $\begin{array}{l}\text { Exposed perimeter } \\
\text { of roof }(\mathrm{m})\end{array}$ & $\begin{array}{c}\text { Goaf } \\
\text { volume } \\
\left(\mathrm{m}^{3}\right)\end{array}$ & $\begin{array}{l}\text { Results of stability } \\
\text { graph method }\end{array}$ \\
\hline 848-1\# & $\begin{array}{c}\text { Of } 3-5 \\
\text { line }\end{array}$ & 35 & 15 & 15 & 525 & 100 & 549.7 & Caving zone \\
\hline 848-2\# & 3-5 line & 20 & 15 & 13 & 260 & 66 & 419.8 & Caving zone \\
\hline 848-3\# & $\begin{array}{c}\text { Of 5-7 } \\
\text { line }\end{array}$ & 32 & 20 & 10 & 320 & 84 & 353.1 & Caving zone \\
\hline $848-4 \#$ & 5-7 line & 30 & 12 & 12 & 360 & 84 & 351.9 & Caving zone \\
\hline $848-5 \#$ & 7-9 line & 39 & 20 & 10 & 390 & 98 & 444.4 & Caving zone \\
\hline $848-6 \#$ & 9-11 line & 42 & 20 & 7 & 294 & 98 & 287.2 & Transition zone \\
\hline $848-7 \#$ & 9-11 line & 41 & 20 & 5 & 205 & 92 & 164.0 & Transition zone \\
\hline $848-8 \#$ & 9-11 line & 20 & 20 & 5 & 100 & 50 & 108.3 & Transition zone \\
\hline 848-9\# & 11-13 line & 40 & 20 & 2 & 80 & 84 & 381.2 & Stable zone \\
\hline $848-10 \#$ & 11-13 line & 40 & 20 & 8 & 320 & 96 & 95.1 & Caving zone \\
\hline $848-11 \#$ & 19-21 line & 45 & 18 & 15 & 675 & 120 & 706.1 & Caving zone \\
\hline $848-12 \#$ & 21-23 line & 42 & 22 & 15 & 630 & 114 & 1175.0 & Caving zone \\
\hline $848-13 \#$ & 23-25 line & 40 & 30 & 5 & 200 & 90 & 405.3 & Transition zone \\
\hline $848-14 \#$ & 25-27 line & 40 & 34 & 12 & 480 & 104 & 1103.6 & Caving zone \\
\hline $848-15 \#$ & 27-29 line & 35 & 34 & 8 & 280 & 86 & 667.9 & Transition zone \\
\hline $848-16 \#$ & 29-31 line & 35 & 34 & 8 & 280 & 86 & 616.5 & Transition zone \\
\hline $848-17 \#$ & 31-33 line & 41 & 34 & 7 & 287 & 96 & 576.6 & Transition zone \\
\hline 848-18\# & 31-35 line & 41 & 34 & 4 & 164 & 90 & 393.4 & Transition zone \\
\hline 848-19\# & 35-37 line & 42 & 34 & 3 & 126 & 90 & 220.1 & Transition zone \\
\hline $848-20 \#$ & 53-55 line & 30 & 4 & 58 & 1740 & 176 & 195.1 & Caving zone \\
\hline $848-21 \#$ & 55-57 line & 42 & 30 & 45 & 1890 & 174 & 2408.9 & Caving zone \\
\hline $848-22 \#$ & 57-59 line & 45.5 & 35 & 2.5 & 113.75 & 96 & 1255.2 & Stable zone \\
\hline $848-23 \#$ & 57-59 line & 32 & 34 & 9 & 288 & 82 & 5993.7 & Transition zone \\
\hline $848-24 \#$ & 61-63 line & 45.2 & 15 & 3 & 135.6 & 96.4 & 795.0 & Stable zone \\
\hline $848-25 \#$ & 63-65 line & 40 & 34 & 4.5 & 180 & 89 & 4680.7 & Stable zone \\
\hline $848-26 \#$ & 67-69 line & 40 & 20 & 7 & 280 & 94 & 5566.0 & Transition zone \\
\hline Total & & & & & 29913.8 & & & \\
\hline
\end{tabular}

7 collapsed stopes in the eastern area, and the volume of the residual mined-out areas accounts for $5.8 \%$ of the stope volume. According to this qualitative estimation, all goaf volumes from the $808 \mathrm{~m}$ to $888 \mathrm{~m}$ level can be obtained as shown in Tables 3 to 5 . The results of cavity scanning based on CMS detection provide the data basis for the backfilling quantity required by the subsequent cavity management.

\section{Goaf Treatment by Precise Backfill Technology}

This study implemented the backfill process based on the principle of precision backfill in goaf. The goaf precision backfill technology is to study the precision backfill theory according to the surrounding rock mass conditions and mainly solve the five problems, namely "how much to fill, what to fill, when to fill, how to fill, and what effect." The specific technical ideas are as follows: firstly, the 3D laser scanning of the goaf is carried out according to CMS to realize the rapid reconstruction of the $3 \mathrm{D}$ contour of the goaf. Secondly, the joint and fissure structure characterization, the stability analysis of the goaf, and the numerical reconstruction of the three-dimensional shape are carried out. Again, the rock sample drilled from the site was tested, and the corresponding mechanical properties were obtained. The physical and chemical characteristics of the tailings were analyzed. The mechanical characteristics of the relationship between the hardened backfill and the nearby rock mass, the matching relationship between the creep deformation of the nearby rock mass, and the backfill were analyzed to realize the configuration of the backfill type and backfill scheme according to the deformation conditions of the nearby rock. Then, as said by the precise detection and numerical reconstruction of the goaf, the stability analysis results of the goaf, and the accurate matching relationship between the backfill and the nearby rock mass, the type and quantity of backfill needed for a specific goaf were calculated to realize the precise backfill of goaf. Finally, the applicability of the treatment scheme using backfill was verified in the combination of the results of the distribution of the nearby rock failure zone and the monitored data of surface subsidence.

4.1. Integrated Planning. As stated by field investigation, there are 101 mined-out areas, including 68 in the west and 33 in the east. Most of the goaf in the west area has a large volume, large exposed roof area, and poor stability. The existence of goaf has caused great hidden trouble to safety production. Combined with the production practice of Alhada lead-zinc mine and according to the distribution characteristics of goaf, the overall planning scheme of goaf 
Table 5: Statistical results of goaf volume in $888 \mathrm{~m}$ level.

\begin{tabular}{|c|c|c|c|c|c|c|c|c|}
\hline $\begin{array}{l}\text { Stop } \\
\text { number }\end{array}$ & $\begin{array}{c}\text { Stope } \\
\text { position }\end{array}$ & $\begin{array}{c}\text { Stope } \\
\operatorname{span}(\mathrm{m})\end{array}$ & $\begin{array}{c}\text { Stope } \\
\text { height }(\mathrm{m})\end{array}$ & $\begin{array}{c}\text { Stope } \\
\text { thickness }(\mathrm{m})\end{array}$ & $\begin{array}{l}\text { Exposed area of } \\
\text { roof }\left(\mathrm{m}^{2}\right)\end{array}$ & $\begin{array}{c}\text { Exposed perimeter } \\
\text { of roof }(\mathrm{m})\end{array}$ & $\begin{array}{c}\text { Goaf } \\
\text { volume } \\
\left(\mathrm{m}^{3}\right)\end{array}$ & $\begin{array}{l}\text { Results of stability } \\
\text { graph method }\end{array}$ \\
\hline $888-1 \#$ & 9-11 line & 41.5 & 18 & 6 & 249 & 95 & 247.1 & Transition zone \\
\hline $888-2 \#$ & 11-13 line & 41.5 & 15 & 5 & 207.5 & 93 & 148.6 & Transition zone \\
\hline $888-3 \#$ & 17-19 line & 41 & 25 & 3 & 123 & 88 & 192.2 & Transition zone \\
\hline $888-4 \#$ & 21-23 line & 41 & 25 & 3 & 123 & 88 & 190.6 & Caving zone \\
\hline $888-5 \#$ & 23-25 line & 42 & 25 & 20 & 840 & 124 & 1051.0 & Caving zone \\
\hline $888-6 \#$ & 25-27 line & 41 & 30 & 5 & 205 & 92 & 232.1 & Transition zone \\
\hline $888-7 \#$ & 25-27 line & 42 & 25 & 5 & 210 & 94 & 643.7 & Transition zone \\
\hline $888-8 \#$ & 27-27 line & 42 & 30 & 15 & 630 & 114 & 1133.7 & Caving zone \\
\hline 888-9\# & 27-29 line & 41 & 25 & 3 & 123 & 88 & 77.1 & Stable zone \\
\hline $888-10 \#$ & 27-29 line & 42 & 25 & 5 & 210 & 94 & 242.2 & Transition zone \\
\hline $888-11 \#$ & 29-31 line & 42 & 20 & 10 & 420 & 104 & 655.6 & Caving zone \\
\hline $888-12 \#$ & 29-31 line & 41 & 30 & 6 & 246 & 94 & 451.0 & Transition zone \\
\hline 888-13\# & 31-33 line & 43 & 8 & 18 & 774 & 122 & 319.3 & Caving zone \\
\hline $888-14 \#$ & 31-33 line & 43 & 34 & 5 & 215 & 96 & 323.1 & Transition zone \\
\hline $888-15 \#$ & 33-35 line & 44 & 34 & 17 & 748 & 122 & 1138.5 & Caving zone \\
\hline $888-16 \#$ & 35-37 line & 44 & 34 & 6.5 & 286 & 101 & 572.9 & Transition zone \\
\hline $888-17 \#$ & 37-39 line & 42 & 34 & 3 & 126 & 90 & 459.2 & Stable zone \\
\hline $888-18 \#$ & 39-41 line & 41 & 10 & 2 & 82 & 86 & 37.8 & Stable zone \\
\hline 888-19\# & 55-57 line & 10 & 8 & 5 & 50 & 30 & 3177.9 & Stable zone \\
\hline $888-20 \#$ & 55-57 line & 5 & 15 & 15 & 75 & 40 & 230.8 & Stable zone \\
\hline $888-21 \#$ & 57-59 line & 10.3 & 12 & 4 & 41.2 & 28.6 & 1413.1 & Stable zone \\
\hline $888-22 \#$ & 59-61 line & 30.2 & 8 & 10 & 302 & 80.4 & 2005.9 & Transition zone \\
\hline $888-23 \#$ & 61-63 line & 27.2 & 15 & 7 & 190.4 & 68.4 & 2782.0 & Transition zone \\
\hline $888-24 \#$ & 63-65 line & 38.9 & 14 & 2 & 77.8 & 81.8 & 2653.3 & Stable zone \\
\hline $888-25 \#$ & 63-65 line & 45 & 14 & 8 & 360 & 106 & 863.9 & Transition zone \\
\hline $888-26 \#$ & 65-67 line & 24 & 15 & 2 & 48 & 52 & 601.9 & Stable zone \\
\hline $888-27 \#$ & $65-67$ line & 22.8 & 15 & 3 & 68.4 & 51.6 & 534.3 & Stable zone \\
\hline $888-28 \#$ & 65-67 line & 21.4 & 15 & 3 & 64.2 & 48.8 & 479.1 & Stable zone \\
\hline $888-29 \#$ & 67-69 line & 21.9 & 14 & 2 & 43.8 & 47.8 & 621.4 & Stable zone \\
\hline 888-30\# & 67-69 line & 20.8 & 15 & 6.5 & 135.2 & 54.6 & 179.4 & Stable zone \\
\hline $888-31 \#$ & 69-71 line & 33.8 & 6 & 10 & 338 & 87.6 & 824.2 & Transition zone \\
\hline 888-32\# & 69-71 line & 40 & 7.5 & 2 & 80 & 84 & 264.6 & Stable zone \\
\hline Total & & & & & 24747.5 & & & \\
\hline
\end{tabular}

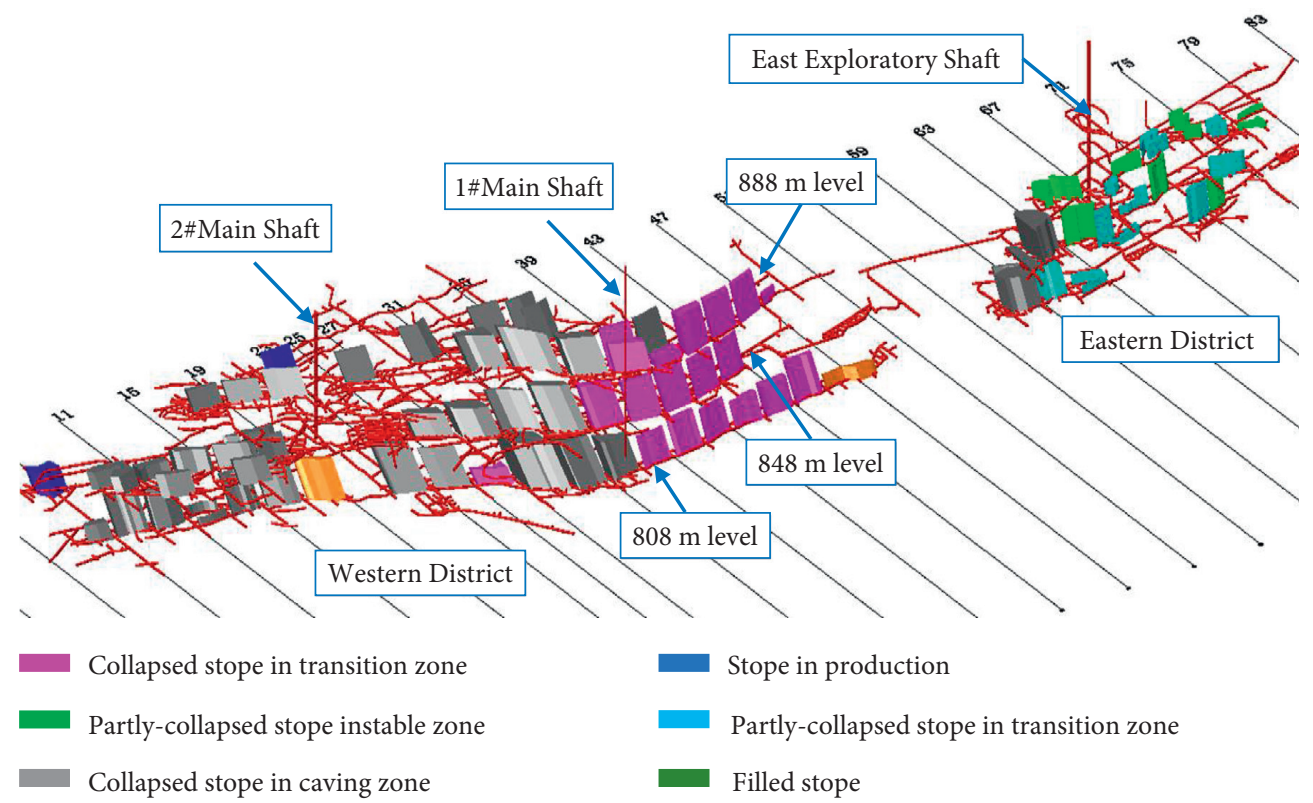

Figure 7: 3D graph of stope stability modified by the Mathews Stability Graph method. 


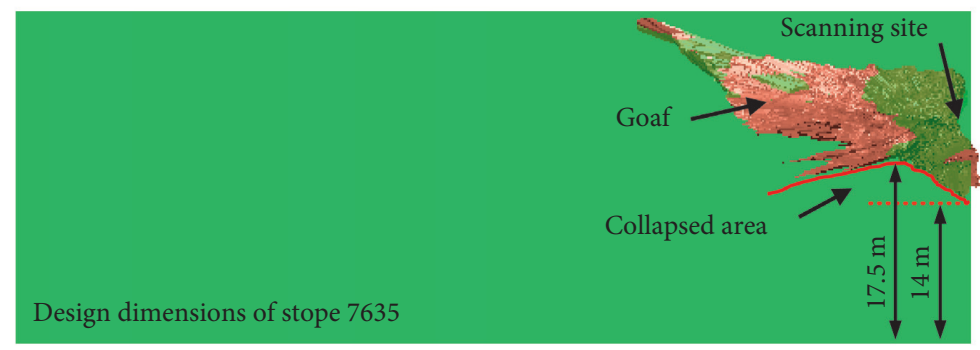

(a)
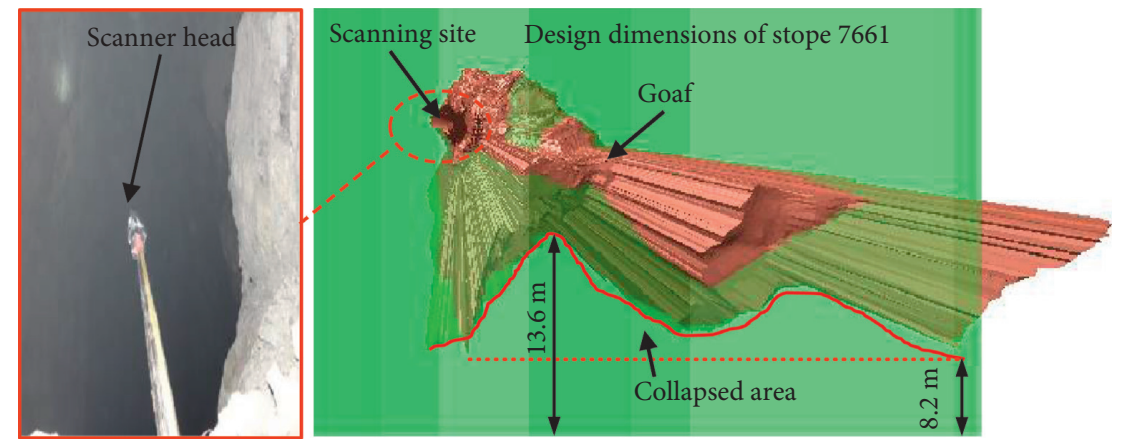

(b)

FiguRE 8: Scanning results of roof caving stopes 7635 (a) and 7661 (b).

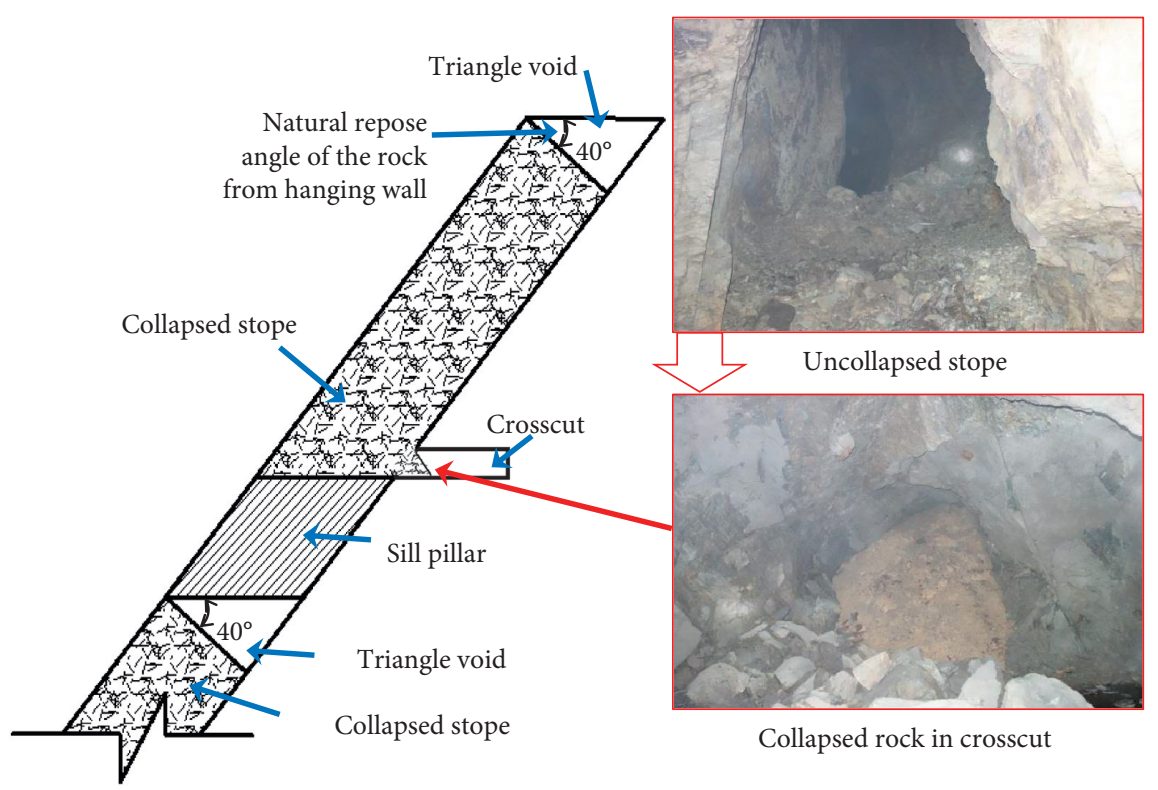

FIGURE 9: The shape of the collapsed stope in the west of $888 \mathrm{~m}$ middle section to $808 \mathrm{~m}$ middle section.

backfilling treatment is determined as follows: the overall sequence of backfilling treatment is from bottom to top, i.e., backfilling the $768 \mathrm{~m}$ level first, followed by backfilling the $808 \mathrm{~m}$ level, $848 \mathrm{~m}$ level, and $888 \mathrm{~m}$ level. Meanwhile, because of the large thickness of 27 to 33 orebody, the mined-out area of 27 to 33 lines is firstly backfilled in the west area, and then, the residual mining is gradually backfilled in the two wings. There is a broken zone in lines 53 to 57 . The goaf at the footwall of the broken zone is, firstly, backfilled in the eastern area, and the residual mining is gradually backfilled from the broken zone eastward. Consistent with the field monitoring results of the deformation rate of a nearby rock mass in stopes 7661 and 7635, the deformation rate of the nearby rock mass belongs to the category of medium strain rate $(0.3 \%$ to $1.5 \% /$ day $)$. As said by the author's earlier research results, when the thickness of the orebody is less than or equal to $6 \mathrm{~m}$, it is necessary to analyze whether the damage and failure of the cemented backfill will occur under 
the condition of a medium strain rate. If the damage/failure is large, the uncemented backfill rather than the cemented backfill should be considered. As the thickness of the orebody is larger than $6 \mathrm{~m}$, cemented backfill should be selected. At this time, the initial stiffness and the minimum shrinkage strain/drainage of the backfill should be taken into account. The statistical results of the backfill types of each goaf are shown in Table 6.

\subsection{Performance Evaluation of Cemented Tailings Backfill.} Because of low-temperature and high-cold conditions in the mining area, the lowest temperature reaches $-37.4^{\circ} \mathrm{C}$, which can cause wellbore icing and surface pipeline cracking. Therefore, the influence of the low-temperature environment conservation on the backfill strength should be considered. According to the climatic conditions and physical and chemical properties of the tailings in the Alhada leadzinc mine, the graded tailings are selected as the filling aggregate, and pulping is made in a low-temperature environment. The useful metal grade in the tailings of Alhada lead-zinc mine is lower than the lowest optional grade. The content of $\mathrm{SiO}_{2}$ and $\mathrm{Al}_{2} \mathrm{O}_{3}$ in the tailings is as high as $56.24 \%$ and $17.82 \%$, respectively. The total content of $\mathrm{SiO}_{2}, \mathrm{Al}_{2} \mathrm{O}_{3}$, and $\mathrm{Fe}_{2} \mathrm{O}_{3}$ is as high as $85 \%$, showing high potential cementation. However, there is a certain amount of sulfur in the tailings, and the mechanical properties of the cemented backfill with the cementing materials need to be determined by test. Thus, the slurry was poured into the standard metal test mold of $7.07 \times 7.07 \times 7.07 \mathrm{~cm}$ and put into the curing box for low-temperature environment curing (curing temperature $7^{\circ} \mathrm{C}$, humidity $90 \%$ ). After reaching the specified curing age, the mold was removed, and the uniaxial compressive strength was tested on a special loading machine. The strength of the backfill with the cement-sand ratio of $1: 4$ to $1: 10$ and the solid content of $65 \%$ to $75 \%$ of the graded tailings in the Alhada lead-zinc mine was studied (including the ages of $7,14,28$, and 60 days). At the same time, the bleeding performance of the filling slurry of the classified tailings of Alhada lead-zinc mine with a cement-sand ratio of $1: 4$ to $1: 10$ and a solid content of $65 \%$ to $75 \%$ was determined. Figure 10 indicates the obtained results.

As the cement-tailings ratio decreased, the compressive strength of the cemented backfill decreased clearly. For example, when the solid content is $75 \%$, the internal structure of $1: 6$ sample is relatively dense. Its compressive strength can reach approximately $1.64 \mathrm{MPa}$ at 28 days, while the compressive strength of $1: 10$ sample at 28 days is only $0.48 \mathrm{MPa}$, and there are stratification and segregation phenomena. The strength of the sample increases with the increase of curing time. For example, the strength of each solid content for 28 days increases significantly compared to that for 7 days. The higher the solid content, the greater the increase range, indicating that the strength increases significantly and lasts for a long time when the cement content in the backfill is larger, which is beneficial to the subsequent backfill.

The strength of backfill is closely related to its solid content. The greater the slurry solid content, the larger the backfill strength [39]. The test results show that when the slurry solid content surges from $65 \%$ to $75 \%$, the strength of the cemented backfill up to 28 days can increase by 2 to 3 times. However, because of the strong workability and viscosity of the cemented-tailings backfill, too high a solid content will make pipeline transportation difficult. The test results show that when the cement-sand ratio is less than 1 : 6 , even if the solid content increases, the strength of the backfill cannot reach $1 \mathrm{MPa}$ in 28 days. When the cementsand ratio is $1: 8$ and $1: 10$, it cannot be used as the cementing layer, which will affect the operation of the mechanical and human activity on the backfill.

The nonuniformity coefficient of the tailings of Alhada lead-zinc mine is 16.5. The particle size distribution of the tailings varies greatly. Approximately $67 \%$ of the tailings particles were less than $75 \mu \mathrm{m}$. The tailings of Alhada leadzinc mine belong to silt, which may lead to slime if it is backfilled into the stope. The nonuniformity coefficient of the graded tailings is 3.9 , and the particle size distribution of the tailings is close to the ideal nonuniformity coefficient of 4 to 5 . It belongs to uniform fine tailings, and the mud content is less than $1 \%$. It is easy to be mixed during pulping, is convenient for pipeline transportation, and is dehydrated rapidly after backfilling in the stope, which is conducive to reducing cement segregation.

The permeability coefficient of Alhada lead-zinc tailings is $0.0702 \mathrm{~cm} / \mathrm{h}$ at $5{ }^{\circ} \mathrm{C}$ and only $0.2376 \mathrm{~cm} / \mathrm{h}$ even at $20^{\circ} \mathrm{C}$. It cannot meet the requirement of $10 \mathrm{~cm} / \mathrm{h}$. It is not conducive to the rapid dehydration and hardening of the backfill and is not suitable for filling aggregate. The permeability of the graded tailings is $3.1428 \mathrm{~cm} / \mathrm{h}$ at $5{ }^{\circ} \mathrm{C}$ and $14.04 \mathrm{~cm} / \mathrm{h}$ at $20^{\circ} \mathrm{C}$. Although the low-temperature environment has a certain influence on the permeability of the graded tailings, it maintains a good dehydration performance and fast initial setting after entering the stope.

4.3. Industrial Tests. The backfill slurry is transported by the pipeline. To make full use of mine tunnels, backfill pipes are arranged in two directions from the surface backfill station outlet to 2\# main shaft and 57 line vents through the surface. The total length of the pipes from the backfill station to $2 \#$ main shaft is $680 \mathrm{~m}$, and the vertical height is $57 \mathrm{~m}$. The total length of the backfill station to 57 line vents is $937 \mathrm{~m}$, and the vertical height is $67 \mathrm{~m}$. See Figure 11(a) for the surface layout of the pipe. The backfill treatment of the mined-out area at $768 \mathrm{~m}$ level was, firstly, carried out in the Alhada lead-zinc mine. Preparation work was made for the backfill of the $25^{\text {th }}$ to $35^{\text {th }}$ line goaf in the $768 \mathrm{~m}$ level. 15 backfill holes were constructed and 18 slab walls were erected. The backfill pipe extends downward from the cable that runs through the surface to the $808 \mathrm{~m}$ level, and the feeding port of the pipe is connected with the filling hole of $ø 100 \mathrm{~mm}$ (Figure 11(b)). Considering the backfill cost, three types of cement/sand ratio of backfill materials are adopted: $1: 6,1: 8$, and pure tailings. The bottom layer of the goaf was, firstly, backfilled with a backfill slurry with a cement-sand ratio of $1: 6$ to a vertical height of $1 \mathrm{~m}$. After that, the whole goaf was backfilled with a cement-sand ratio of $1: 8$. The solid content 
TABLE 6: Statistical results of the types of backfill (collapsed rock and cemented/uncemented backfill) in each middle goaf.

\begin{tabular}{|c|c|c|c|c|c|}
\hline $\begin{array}{l}\text { Stope } \\
\text { number }\end{array}$ & $\begin{array}{l}\text { The ratio of the volume of the } \\
\text { collapsed waste rock to the total } \\
\text { volume of the goaf }(\%)\end{array}$ & Types of backfill & $\begin{array}{c}\text { Stope } \\
\text { number }\end{array}$ & $\begin{array}{l}\text { The ratio of the volume of the } \\
\text { collapsed waste rock to the total } \\
\text { volume of the goaf }(\%)\end{array}$ & Types of backfill \\
\hline $768-1 \#$ & 49 & $\begin{array}{c}\text { Cemented } \\
\text { backfill }\end{array}$ & $848-12 \#$ & 94 & $\begin{array}{c}\text { Cemented } \\
\text { backfill }\end{array}$ \\
\hline 768-2\# & 49 & $\begin{array}{c}\text { Cemented } \\
\text { backfill }\end{array}$ & $848-13 \#$ & 94 & $\begin{array}{c}\text { Cemented } \\
\text { backfill }\end{array}$ \\
\hline 768-3\# & 49 & $\begin{array}{c}\text { Cemented } \\
\text { backfill }\end{array}$ & $848-14 \#$ & 94 & $\begin{array}{c}\text { Cemented } \\
\text { backfill }\end{array}$ \\
\hline 768-4\# & 49 & $\begin{array}{c}\text { Cemented } \\
\text { backfill }\end{array}$ & $848-15 \#$ & 94 & $\begin{array}{c}\text { Cemented } \\
\text { backfill }\end{array}$ \\
\hline $768-5 \#$ & 49 & $\begin{array}{l}\text { Uncemented } \\
\text { backfill }\end{array}$ & $848-16 \#$ & 94 & $\begin{array}{c}\text { Cemented } \\
\text { backfill }\end{array}$ \\
\hline 768-6\# & 49 & $\begin{array}{c}\text { Uncemented } \\
\text { backfill }\end{array}$ & $848-17 \#$ & 94 & $\begin{array}{c}\text { Cemented } \\
\text { backfill }\end{array}$ \\
\hline $768-7 \#$ & 49 & $\begin{array}{c}\text { Cemented } \\
\text { backfill }\end{array}$ & $848-18 \#$ & 94 & $\begin{array}{c}\text { Cemented } \\
\text { backfill }\end{array}$ \\
\hline $768-8 \#$ & 34 & $\begin{array}{c}\text { Cemented } \\
\text { backfill }\end{array}$ & 848-19\# & 94 & $\begin{array}{l}\text { Uncemented } \\
\text { backfill }\end{array}$ \\
\hline 768-9\# & 34 & $\begin{array}{c}\text { Cemented } \\
\text { backfill }\end{array}$ & $848-20 \#$ & 94 & $\begin{array}{c}\text { Cemented } \\
\text { backfill }\end{array}$ \\
\hline 808-1\# & 94 & $\begin{array}{c}\text { Cemented } \\
\text { backfill }\end{array}$ & $848-21 \#$ & 94 & $\begin{array}{c}\text { Cemented } \\
\text { backfill }\end{array}$ \\
\hline 808-2\# & 94 & $\begin{array}{c}\text { Cemented } \\
\text { backfill }\end{array}$ & $848-22 \#$ & 0 & $\begin{array}{l}\text { Uncemented } \\
\text { backfill }\end{array}$ \\
\hline 808-3\# & 94 & $\begin{array}{c}\text { Cemented } \\
\text { backfill }\end{array}$ & $848-23 \#$ & 0 & $\begin{array}{c}\text { Cemented } \\
\text { backfill }\end{array}$ \\
\hline $808-4 \#$ & 94 & $\begin{array}{l}\text { Uncemented } \\
\text { backfill }\end{array}$ & $848-24 \#$ & 0 & $\begin{array}{l}\text { Uncemented } \\
\text { backfill }\end{array}$ \\
\hline $808-5 \#$ & 94 & $\begin{array}{l}\text { Cemented } \\
\text { backfill }\end{array}$ & $848-25 \#$ & 0 & $\begin{array}{l}\text { Cemented } \\
\text { backfill }\end{array}$ \\
\hline $808-6 \#$ & 94 & $\begin{array}{c}\text { Cemented } \\
\text { backfill }\end{array}$ & $848-26 \#$ & 0 & $\begin{array}{c}\text { Cemented } \\
\text { backfill }\end{array}$ \\
\hline $808-7 \#$ & 94 & $\begin{array}{c}\text { Cemented } \\
\text { backfill }\end{array}$ & $888-1 \#$ & 94 & $\begin{array}{l}\text { Uncemented } \\
\text { backfill }\end{array}$ \\
\hline $808-8 \#$ & 94 & $\begin{array}{c}\text { Cemented } \\
\text { backfill }\end{array}$ & 888-2\# & 94 & $\begin{array}{c}\text { Cemented } \\
\text { backfill }\end{array}$ \\
\hline 808-9\# & 94 & $\begin{array}{l}\text { Uncemented } \\
\text { backfill }\end{array}$ & 888-3\# & 94 & $\begin{array}{l}\text { Uncemented } \\
\text { backfill }\end{array}$ \\
\hline $808-10 \#$ & 94 & $\begin{array}{l}\text { Uncemented } \\
\text { backfill }\end{array}$ & $888-4 \#$ & 94 & $\begin{array}{l}\text { Uncemented } \\
\text { backfill }\end{array}$ \\
\hline $808-11 \#$ & 94 & $\begin{array}{c}\text { Cemented } \\
\text { backfill }\end{array}$ & $888-5 \#$ & 94 & $\begin{array}{c}\text { Cemented } \\
\text { backfill }\end{array}$ \\
\hline $808-12 \#$ & 94 & $\begin{array}{c}\text { Cemented } \\
\text { backfill }\end{array}$ & 888-6\# & 94 & $\begin{array}{l}\text { Uncemented } \\
\text { backfill }\end{array}$ \\
\hline $808-13 \#$ & 94 & $\begin{array}{c}\text { Cemented } \\
\text { backfill }\end{array}$ & $888-7 \#$ & 94 & $\begin{array}{l}\text { Uncemented } \\
\text { backfill }\end{array}$ \\
\hline $808-14 \#$ & 94 & $\begin{array}{l}\text { Uncemented } \\
\text { backfill }\end{array}$ & 888-8\# & 94 & $\begin{array}{c}\text { Cemented } \\
\text { backfill }\end{array}$ \\
\hline $808-15 \#$ & 94 & $\begin{array}{l}\text { Uncemented } \\
\text { backfill }\end{array}$ & 888-9\# & 94 & $\begin{array}{l}\text { Uncemented } \\
\text { backfill }\end{array}$ \\
\hline $808-16 \#$ & 94 & $\begin{array}{l}\text { Uncemented } \\
\text { backfill }\end{array}$ & 888-10\# & 94 & $\begin{array}{l}\text { Uncemented } \\
\text { backfill }\end{array}$ \\
\hline $808-17 \#$ & 94 & $\begin{array}{l}\text { Uncemented } \\
\text { backfill }\end{array}$ & 888-11\# & 94 & $\begin{array}{c}\text { Cemented } \\
\text { backfill }\end{array}$ \\
\hline $808-18 \#$ & 0 & $\begin{array}{l}\text { Uncemented } \\
\text { backfill }\end{array}$ & $888-12 \#$ & 94 & $\begin{array}{l}\text { Uncemented } \\
\text { backfill }\end{array}$ \\
\hline 808-19\# & 0 & $\begin{array}{l}\text { Uncemented } \\
\text { backfill }\end{array}$ & 888-13\# & 94 & $\begin{array}{c}\text { Cemented } \\
\text { backfill }\end{array}$ \\
\hline $808-20 \#$ & 0 & $\begin{array}{c}\text { Cemented } \\
\text { backfill }\end{array}$ & 888-14\# & 94 & $\begin{array}{l}\text { Uncemented } \\
\text { backfill }\end{array}$ \\
\hline
\end{tabular}


TABLE 6: Continued.

\begin{tabular}{|c|c|c|c|c|c|}
\hline $\begin{array}{l}\text { Stope } \\
\text { number }\end{array}$ & $\begin{array}{l}\text { The ratio of the volume of the } \\
\text { collapsed waste rock to the total } \\
\text { volume of the goaf }(\%)\end{array}$ & Types of backfill & $\begin{array}{c}\text { Stope } \\
\text { number }\end{array}$ & $\begin{array}{l}\text { The ratio of the volume of the } \\
\text { collapsed waste rock to the total } \\
\text { volume of the goaf }(\%)\end{array}$ & Types of backfill \\
\hline $808-21 \#$ & 94 & $\begin{array}{c}\text { Cemented } \\
\text { backfill }\end{array}$ & $888-15 \#$ & 94 & $\begin{array}{c}\text { Cemented } \\
\text { backfill }\end{array}$ \\
\hline $808-22 \#$ & 94 & $\begin{array}{c}\text { Cemented } \\
\text { backfill }\end{array}$ & 888-16\# & 94 & $\begin{array}{c}\text { Cemented } \\
\text { backfill }\end{array}$ \\
\hline $808-23 \#$ & 0 & $\begin{array}{c}\text { Cemented } \\
\text { backfill }\end{array}$ & 888-17\# & 0 & $\begin{array}{l}\text { Uncemented } \\
\text { backfill }\end{array}$ \\
\hline $808-24 \#$ & 0 & $\begin{array}{c}\text { Cemented } \\
\text { backfill }\end{array}$ & 888-18\# & 0 & $\begin{array}{l}\text { Uncemented } \\
\text { backfill }\end{array}$ \\
\hline $808-25 \#$ & 0 & $\begin{array}{l}\text { Uncemented } \\
\text { backfill }\end{array}$ & 888-19\# & 0 & $\begin{array}{l}\text { Uncemented } \\
\text { backfill }\end{array}$ \\
\hline $808-26 \#$ & 0 & $\begin{array}{l}\text { Uncemented } \\
\text { backfill }\end{array}$ & 888-20\# & 0 & $\begin{array}{c}\text { Cemented } \\
\text { backfill }\end{array}$ \\
\hline $808-27 \#$ & 0 & $\begin{array}{l}\text { Uncemented } \\
\text { backfill }\end{array}$ & $888-21 \#$ & 0 & $\begin{array}{l}\text { Uncemented } \\
\text { backfill }\end{array}$ \\
\hline $808-28 \#$ & 0 & $\begin{array}{l}\text { Uncemented } \\
\text { backfill }\end{array}$ & $888-22 \#$ & 0 & $\begin{array}{c}\text { Cemented } \\
\text { backfill }\end{array}$ \\
\hline 848-1\# & 94 & $\begin{array}{c}\text { Cemented } \\
\text { backfill }\end{array}$ & 888-23\# & 0 & $\begin{array}{c}\text { Cemented } \\
\text { backfill }\end{array}$ \\
\hline 848-2\# & 94 & $\begin{array}{c}\text { Cemented } \\
\text { backfill }\end{array}$ & 888-24\# & 0 & $\begin{array}{c}\text { Uncemented } \\
\text { backfill }\end{array}$ \\
\hline $848-3 \#$ & 94 & $\begin{array}{c}\text { Cemented } \\
\text { backfill }\end{array}$ & $888-25 \#$ & 0 & $\begin{array}{c}\text { Cemented } \\
\text { backfill }\end{array}$ \\
\hline $848-4 \#$ & 94 & $\begin{array}{c}\text { Cemented } \\
\text { backfill }\end{array}$ & $888-26 \#$ & 0 & $\begin{array}{l}\text { Uncemented } \\
\text { backfill }\end{array}$ \\
\hline $848-5 \#$ & 94 & $\begin{array}{c}\text { Cemented } \\
\text { backfill }\end{array}$ & $888-27 \#$ & 0 & $\begin{array}{l}\text { Uncemented } \\
\text { backfill }\end{array}$ \\
\hline $848-6 \#$ & 94 & $\begin{array}{l}\text { Cemented } \\
\text { backfill }\end{array}$ & $888-28 \#$ & 0 & $\begin{array}{l}\text { Uncemented } \\
\text { backfill }\end{array}$ \\
\hline $848-7 \#$ & 94 & $\begin{array}{l}\text { Uncemented } \\
\text { backfill }\end{array}$ & 888-29\# & 0 & $\begin{array}{l}\text { Uncemented } \\
\text { backfill }\end{array}$ \\
\hline $848-8 \#$ & 94 & $\begin{array}{l}\text { Uncemented } \\
\text { backfill }\end{array}$ & 888-30\# & 0 & $\begin{array}{l}\text { Cemented } \\
\text { backfill }\end{array}$ \\
\hline 848-9\# & 94 & $\begin{array}{l}\text { Uncemented } \\
\text { backfill }\end{array}$ & 888-31\# & 0 & $\begin{array}{c}\text { Cemented } \\
\text { backfill }\end{array}$ \\
\hline 848-10\# & 94 & $\begin{array}{c}\text { Cemented } \\
\text { backfill }\end{array}$ & $888-32 \#$ & 0 & $\begin{array}{c}\text { Uncemented } \\
\text { backfill }\end{array}$ \\
\hline $848-11 \#$ & 94 & $\begin{array}{c}\text { Cemented } \\
\text { backfill }\end{array}$ & - & - & - \\
\hline
\end{tabular}

of the slurry is changed between $65 \%$ and $70 \%$. During the backfill process, the drainage wall was closely observed as shown in Figure 11(c). The feeding point and mine backfill amount were adjusted according to the drainage speed, and the backfill method of "multipoint feeding, multiple times with more and less amount" was adopted.

Using the performed field mine backfill industrial testing, only $22,500 \mathrm{~m}^{3}$ of cavity backfill was completed in lines 25 to 35 of the $768 \mathrm{~m}$ level. The maximum backfill amount of a single goaf in a single day reaches $1240 \mathrm{~m}^{3}$ with an average backfill capacity of $60 \mathrm{~m}^{3}$ to $80 \mathrm{~m}^{3}$ per hour. The vertical height of packing is $35 \mathrm{~m}$. No pipe blockage, wall collapse, or slurry leakage occurred during the mine backfill process.
According to the disclosure of $808 \mathrm{~m}$ construction goaf combined roadway, the mine backfill material has good flatness and high compactness. It can meet the requirements of goaf treatment and later sill pillar recovery.

\section{Evaluation of the Effect of Goaf Treatment by Backfill}

In this study, the numerical simulation method was employed to better analyze the damage and failure of the surrounding rock mass in goaf, and the surface subsidence monitoring method was used to analyze the surface 


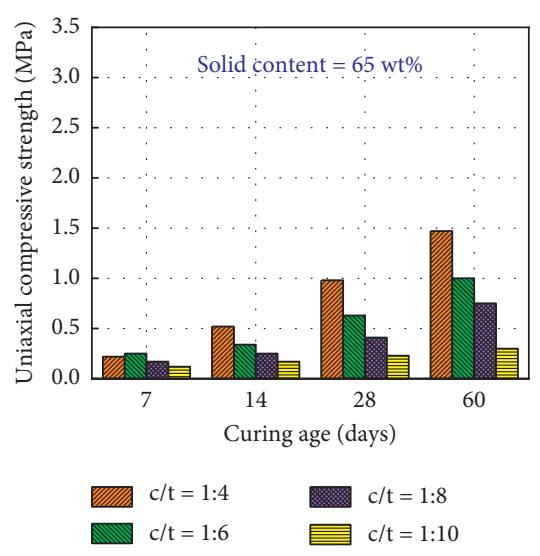

(a)

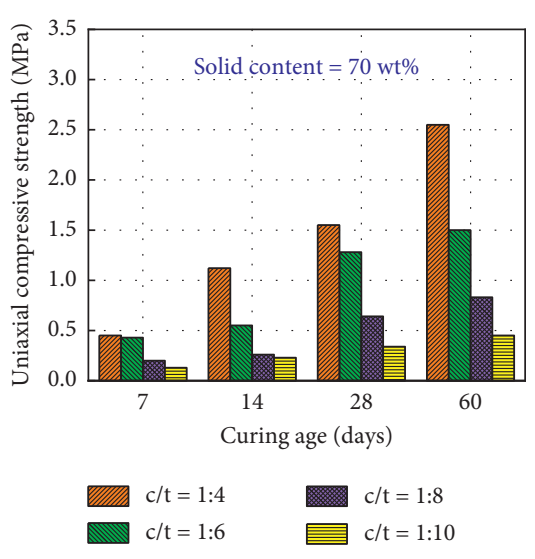

(b)

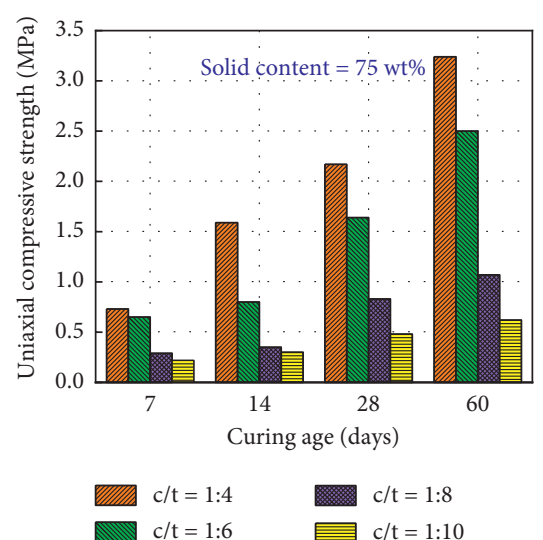

(c)

FIGURE 10: Evolution of the strength of cemented backfill under the effects of solid content and cement-tailings ratio.

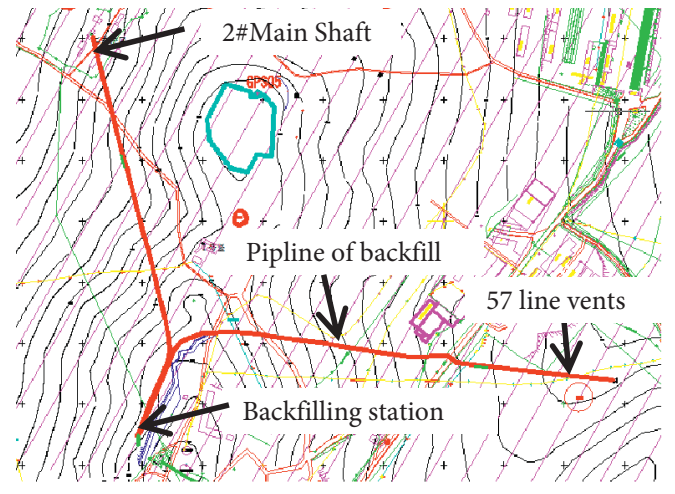

(a)

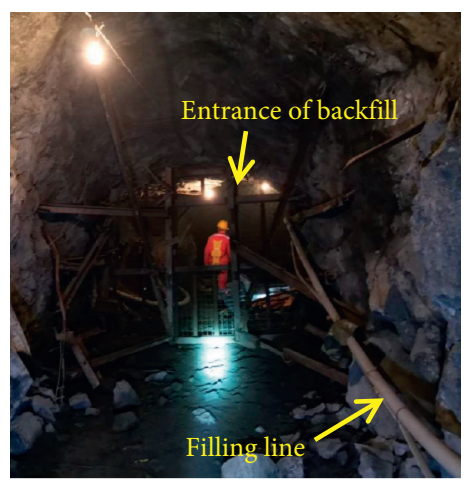

(b)

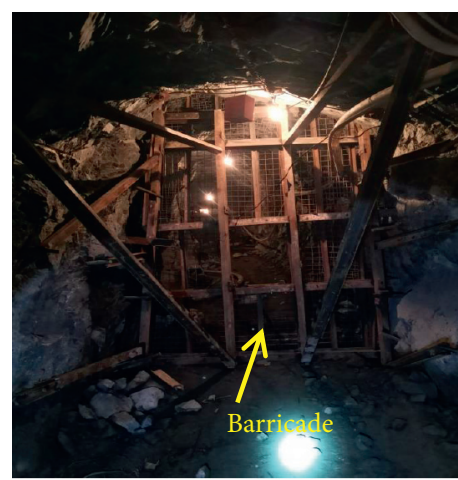

(c)

Figure 11: Industrial test. (a) The layout of backfilling pipeline at surface; (b) entrance of backfill at a goaf; (c) construction of barricades.

subsidence to evaluate the effectiveness of the filling treatment of a large goaf. For details, see sections 5.1 and 5.2.

5.1. Distribution of Surrounding Rock Failure Zone in Goaf. The amount of backfill used in the mined-out area is given in Table 6. It can be seen that every stope is not regular equally in terms of the mine backfill process as demonstrated clearly in Figure 12. However, the volume of backfill in the stope is carried out strictly in accordance with the actual situation of the surrounding rock mass. For example, some stopes have triangular goaf, some use cemented backfill, some use uncemented backfill, and the influence of collapsed waste rock caused by the unstable surrounding rock is considered during the backfill process.

As observed from Figure 13, the surrounding rock of the goaf without the backfill treatment has many failure areas, and the rock pillars between the goaf have large failure areas. One can observe that the failure area of the nearby rock of the goaf is significantly reduced after using the backfill method per the deformation state of the nearby rock mass, and the backfill treatment of the goaf significantly improves the stability of the surrounding rock mass. It shows that the backfill technology adopted in this study has a sizeable influence in governing the stability of the nearby rock mass in the goaf.

5.2. Monitoring Scheme and the Results of Surface Subsidence. To certify the secure production and smooth progress of backfilling treatment, a settlement monitoring system is set up on the surface. The monitoring scheme uses SD-226 hydraulic static level that is composed of a liquid reservoir, imported high-precision core, specially customized circuit module, protective cover, and other components. Four core cables are used to connect each static level in parallel, and then, they are connected to the data gaining port. Two of the four core cables are used for the power supply of the sensor, and the other two are used for data transmission. The data collection port has a built-in wireless module that conveys the monitored data to the cloud data service center through the GPRS network. The monitoring center server accesses the cloud data service center using the HTTP transmission protocol, and the users can query, manage, and maintain projects.

The diameter of the collapse pit at No. 25 exploration line is approximately $125 \mathrm{~m}$ and that at No. 29 exploration line is approximately $70 \mathrm{~m}$. Considering the scope of the surface 


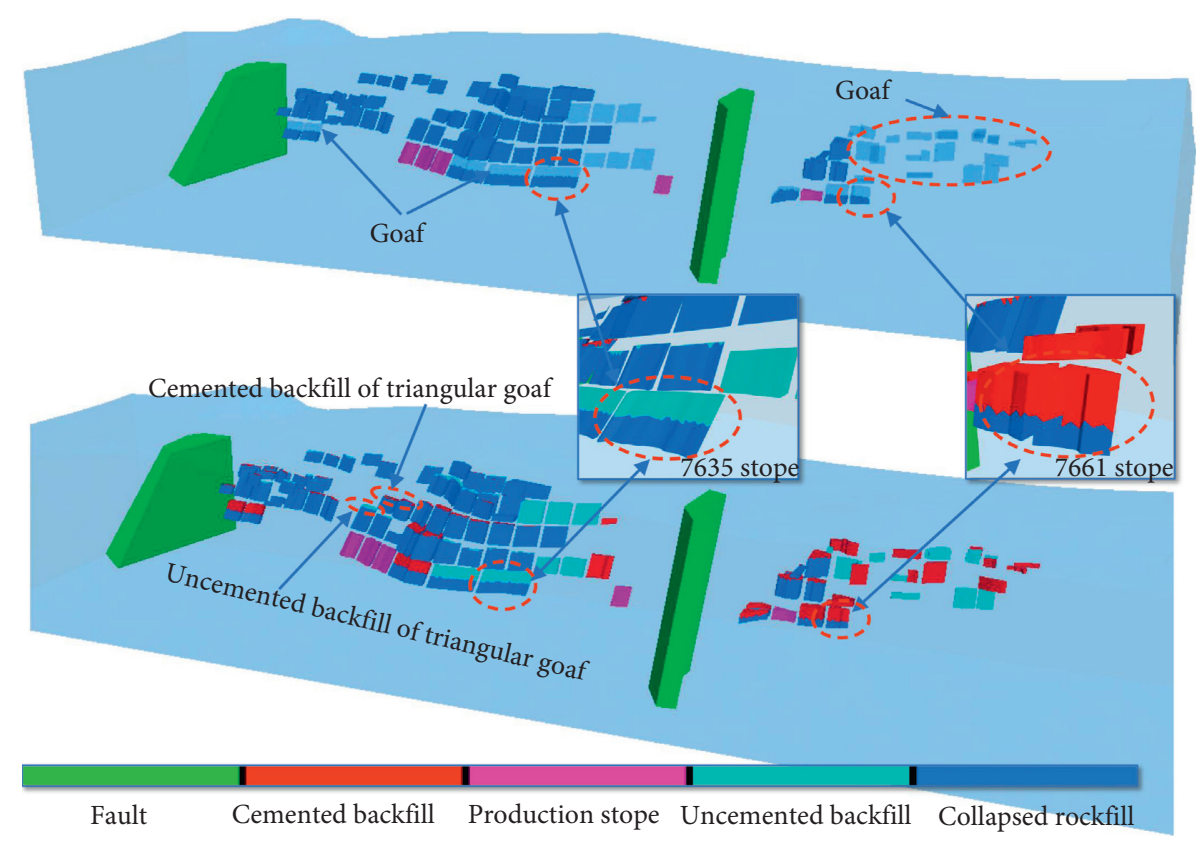

FIGURE 12: Results of precise backfill in large goaf group.

moving belt, the monitoring range of the area is determined from exploration line 23 to exploration line 31 . Ten measuring points are arranged along the $300 \mathrm{~m}$ (S1 monitoring line) and $170 \mathrm{~m}$ (S2 monitoring line) of the orebody strike to monitor the settlement rule of the surface moving belt as shown in Figure 14. The surface liquid static level monitoring system was installed and officially put into operation after debugging.

Figure 15(a) shows the accumulated settlement value of each measuring point in S1. The accumulated settlement value of $\mathrm{N} 2-\mathrm{N} 5$ measuring point fluctuates at $0 \mathrm{~cm}$, and no surface settlement occurs in this monitoring area. The accumulated settlement value of N10 measurement point fluctuates at $2 \mathrm{~cm}$. The N7-N9 measuring point deformation value with time is increasing and then tends to attain a stable state, N7 measuring point accumulated settlement value is about $5.2 \mathrm{~cm}$, N8 measuring point accumulated settlement value is about $7.9 \mathrm{~cm}$, and $\mathrm{N} 9$ measuring point accumulated settlement value is about $5.7 \mathrm{~cm}$.

Figure 15(b) shows the accumulated settlement value of each measuring point in S2. The accumulated settlement value of $\mathrm{N} 2 \sim \mathrm{N} 6$ measuring point fluctuates at $0 \mathrm{~cm}$, and no surface settlement occurs in this monitoring area. N10 began to settle on September 2, and the maximum accumulated settlement value was $8.5 \mathrm{~cm}$. The deformation value of N7-N9 measuring points increases with time and begins to fluctuate periodically on August 10. Finally, the three measuring points tend to stabilize at the settlement value of $8 \mathrm{~cm}$. 


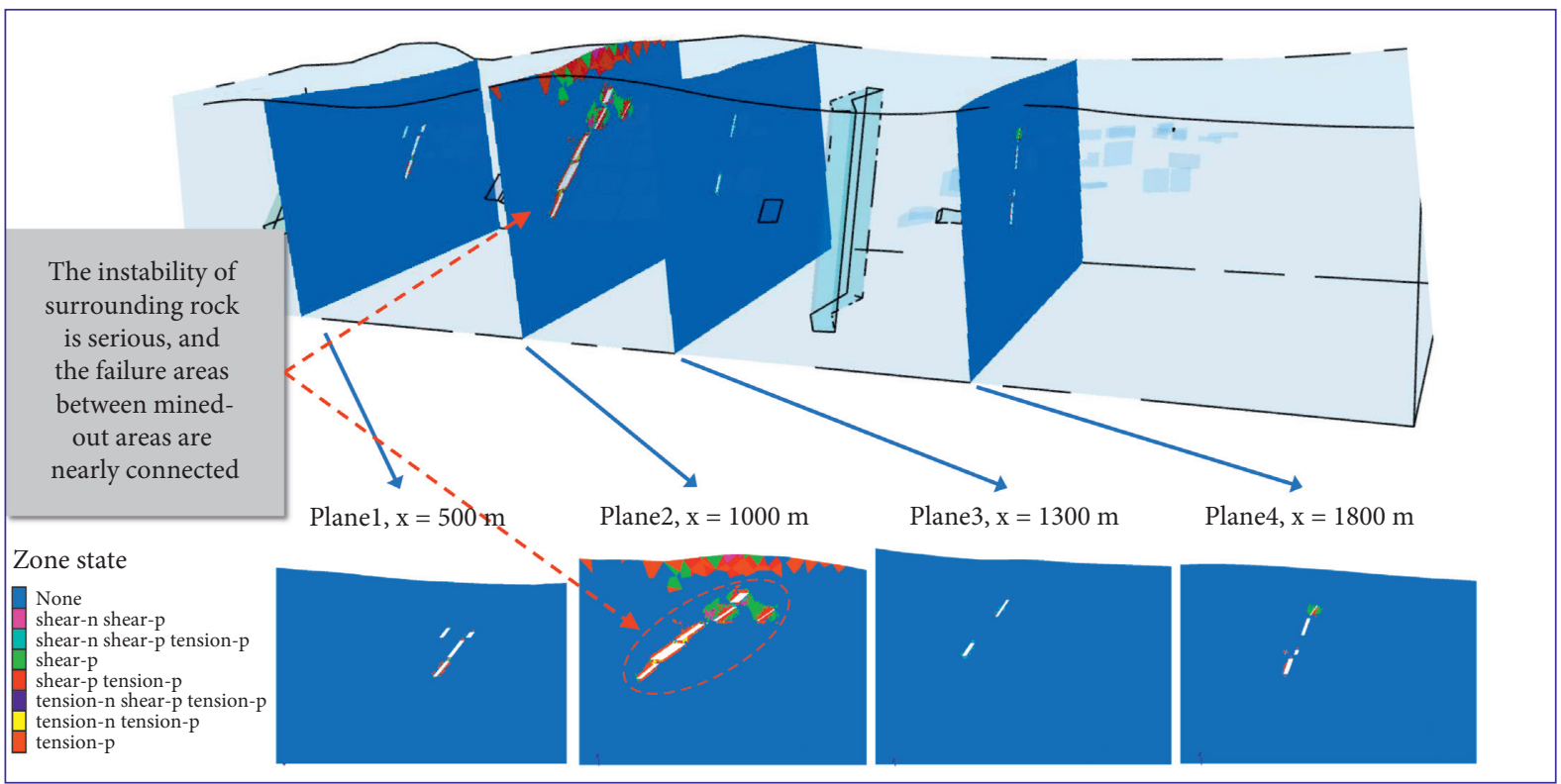

(a)

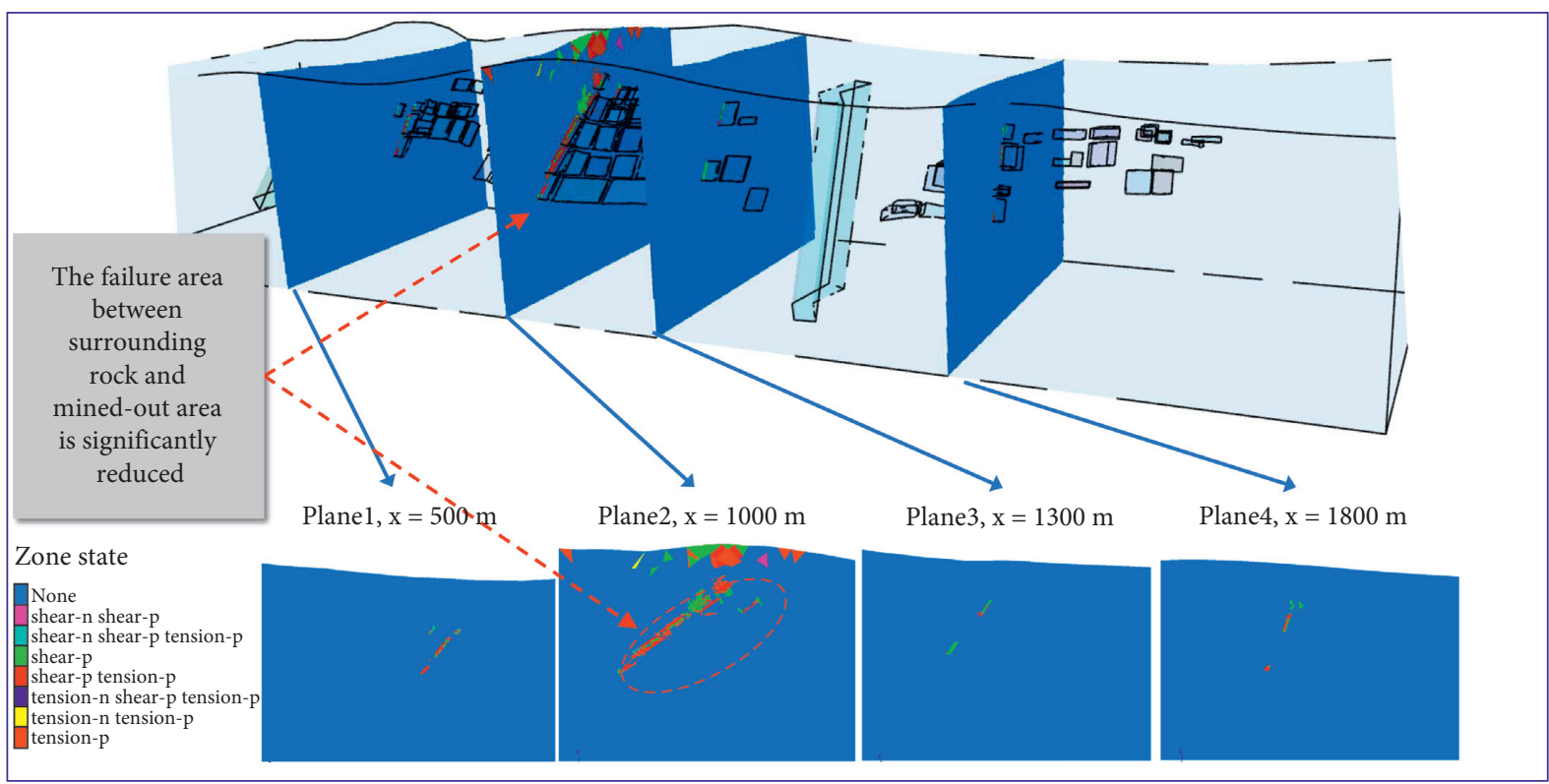

(b)

Figure 13: The failure area of the surrounding rock of the large goaf group using the backfill method and otherwise. (a) Large goaf group that is not backfilled and (b) backfilled per the specific conditions of the surrounding rock mass. 


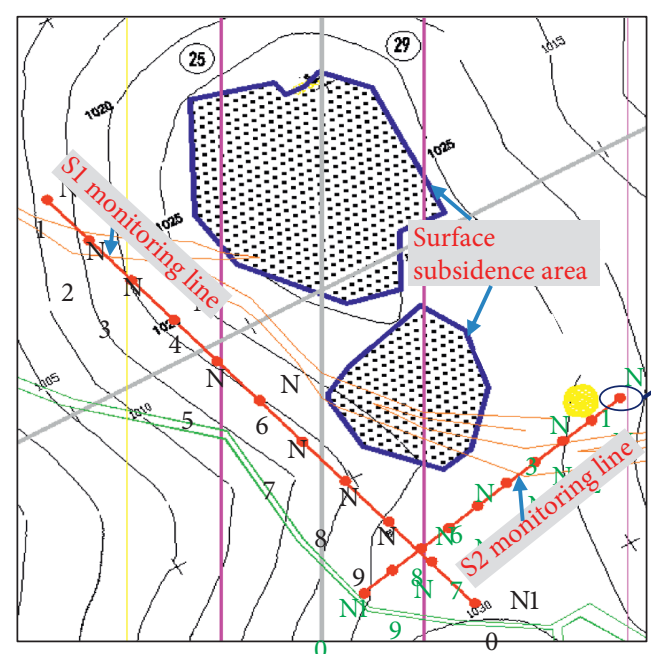

Layout of surface subsidence monitoring points

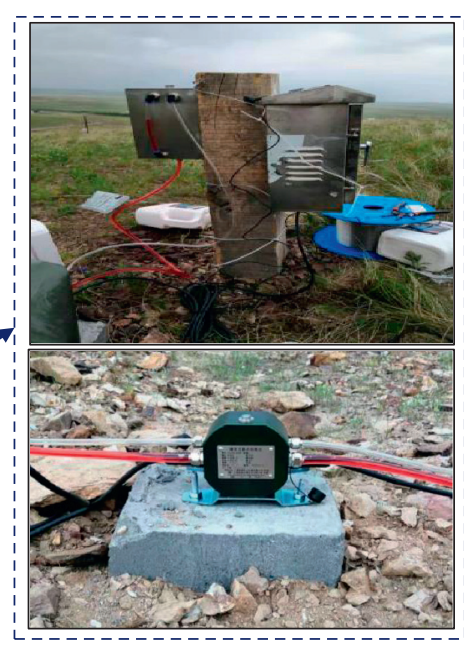

Hydrostatic level system

FIgURE 14: Layout of surface subsidence monitoring points and Hydrostatic Level System.

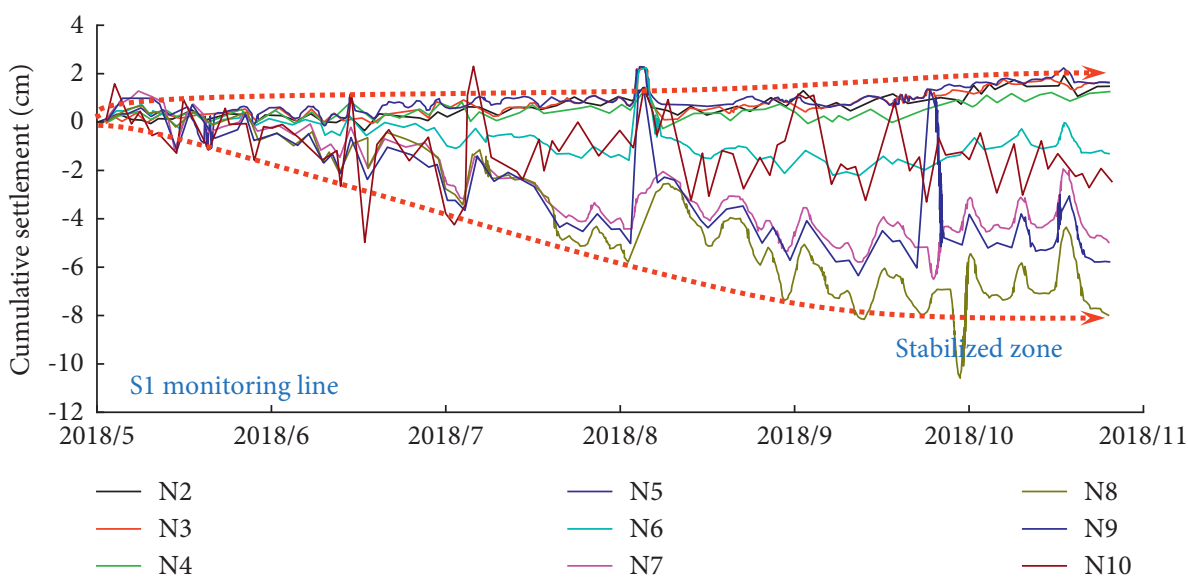

(a)

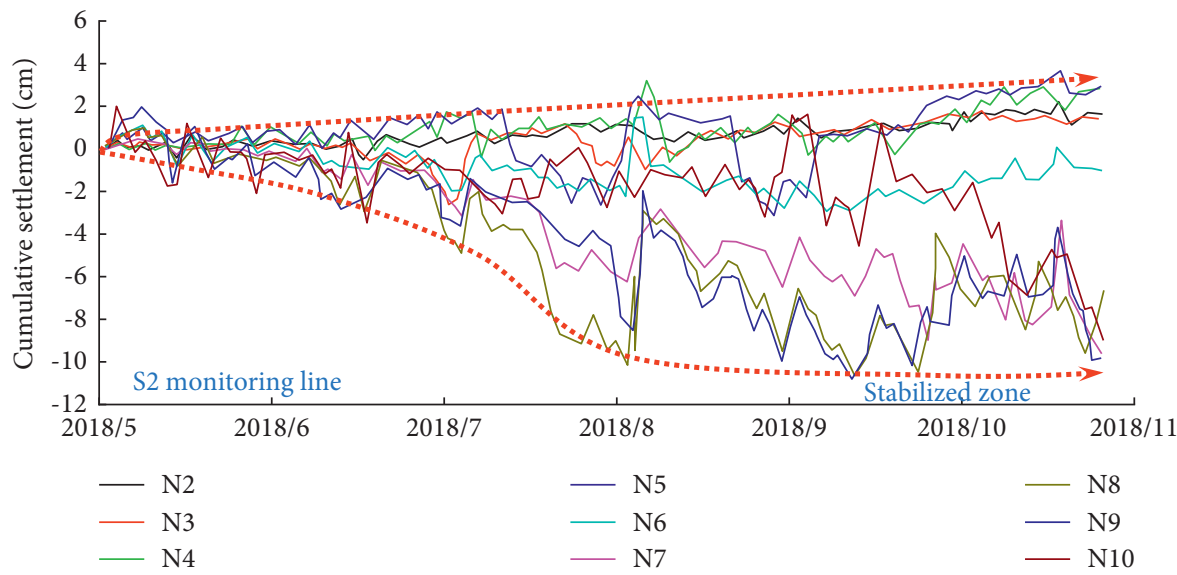

(b)

Figure 15: Cumulative settlement of each measuring point on (a) S1 and (b) S2 monitoring line. 


\section{Conclusions}

In this study, three-dimensional modeling, laboratory test, industrial test, and field monitoring were used to study the treatment scheme of a large goaf group in the Alhada leadzinc mine using precise backfill technology. The specific conclusions are as follows:

(i) The stability of the large goaf group can be comprehensively evaluated by employing the modified Mathews stability diagram system. The volume of each goaf to be backfilled can be quantitatively analyzed in combination with theoretical analysis and three-dimensional laser scanning technology.

(ii) The final collapse form of the western stope is caused by the instability of the upper wall of the goaf, and there is a triangular goaf under the effect of the western goaf and the eastern broken zone. The volume of the triangular goaf accounts for about $5.8 \%$ of the stope volume. The residual mined-out area volume in the western section of $768 \mathrm{~m}$ accounts for $50.9 \%$ of the stope volume. The volume of the residual mined-out area outside the influence area of the broken zone in the eastern area accounts for $65.9 \%$ of the total volume of the stope.

(iii) The precise backfill technology adopted in this study can deal with a large goaf group well and significantly reduce the damaged area of the surrounding rock mass in the goaf and the settlement of the surface. Also, it can reduce the cost of backfill treatment using cemented backfill and uncemented backfill together. The monitoring results showed that the surface maximum accumulated subsidence value is about $8.5 \mathrm{~cm}$, and in the end, the surface vertical deformation tends to be stable after using the backfill technology.

\section{Data Availability}

All data, models, or codes that support the findings of this study are available from the corresponding author upon reasonable request.

\section{Conflicts of Interest}

The authors declare no conflicts of interest.

\section{Acknowledgments}

This work was funded by the National Science Foundation of China (Grant no. U1906208), the fellowship of China Postdoctoral Science Foundation (2021MD703874 and 2021M702015), and Scientific Research Start-Up Project of University Talent Introduction (Grant no. 2050121006). These supports are gratefully acknowledged.

\section{References}

[1] Y. M. Wang, M. Q. Huang, A. X. Wu, G. H. Yao, and K. J. Hu, "Rock backfill and hazard control of abandoned stopes: a case study," Applied Mechanics and Materials, vol. 368-370, pp. 1726-1731, 2013.

[2] X. Zhao, A. Fourie, and C.-C. Qi, "Mechanics and safety issues in tailing-based backfill: a review," International Journal of Minerals, Metallurgy and Materials, vol. 27, no. 9, pp. 1165$1178,2020$.

[3] X. Liu, J. Ning, Y. Tan, Q. Xu, and D. Fan, "Coordinated supporting method of gob-side entry retaining in coal mines and a case study with hard roof," Geomechanics and Engineering, vol. 15, no. 6, pp. 1173-1182, 2018.

[4] U. G. Akkaya, K. Cinku, and E. Yilmaz, "Characterization of strength and quality of cemented mine backfill made up of lead-zinc processing tailings," Frontiers in Materials, vol. 8, Article ID 740116, 2021.

[5] S. Qin, S. Cao, E. Yilmaz, and J. Li, "Effects of types and geometric shapes of $3 \mathrm{D}$ printed polymeric lattice on ductility performance of cementitious backfill composites," Construction and Building Materials, vol. 307, Article ID 124973, 2021.

[6] W. Y. Lv and Z. H. Zhang, "Research on the belt loader waste rock gravity backfill mining technology," Applied Mechanics and Materials, vol. 253, pp. 1036-1039, 2013.

[7] G. L. Xue, E. Yilmaz, W. D. Song, and S. Cao, "Fiber length effect on strength properties of polypropylene fiber reinforced cemented tailings backfill specimens with different sizes," Construction and Building Materials, vol. 241, Article ID 118113, 2020.

[8] L. Cui and M. Fall, "Multiphysics modeling of arching effects in fill mass," Computers and Geotechnics, vol. 83, pp. 114-131, 2017.

[9] S. Yin, Y. Shao, A. Wu, H. Wang, X. Liu, and Y. Wang, "A systematic review of paste technology in metal mines for cleaner production in China," Journal of Cleaner Production, vol. 247, Article ID 119590, 2020.

[10] C. Zhang, S. Tu, and Y. Zhao, "Compaction characteristics of the caving zone in a longwall goaf: a review," Environmental Earth Sciences, vol. 78, no. 1, p. 27, 2019.

[11] F. Ren, Y. Zhou, R. He, J. Cao, and K. Zou, "Similarity model test on the spatiotemporal evolution law of deformation and failure of surrounding rock-induced caving in multi-minedout areas," Advances in Civil Engineering, vol. 2021, Article ID 1224658, 15 pages, 2021.

[12] S. Cao, E. Yilmaz, G. L. Xue, and W. D. Song, "Assessment of acoustic emission and triaxial mechanical properties of rockcemented tailings matrix composites," Advances in Materials Science and Engineering, vol. 2019, Article ID 6742392, 12 pages, 2019.

[13] W. Bao, Z. Ma, H. Wang, J. Ren, Y. Huang, and B. Liang, "Integrated treatment technology of storage-mining inclined goaf under expressway," Advances in Civil Engineering, vol. 2020, Article ID 8822964, 19 pages, 2020.

[14] X. Li, X. Guo, and G. Sun, "Grouting reinforcement mechanism and multimodel simulation analysis of longwall goaf," Geofluids, vol. 2021, Article ID 9943596, 13 pages, 2021.

[15] J.-X. Zhang, P. Huang, Q. Zhang, M. Li, and Z.-W. Chen, "Stability and control of room mining coal pillars-taking room mining coal pillars of solid backfill recovery as an example," Journal of Central South University, vol. 24, no. 5, pp. 1121-1132, 2017.

[16] X. Li, D. Wang, C. Li, and Z. Liu, "Numerical simulation of surface subsidence and backfill material movement induced by underground mining," Advances in Civil Engineering, vol. 2019, Article ID 2724370, 17 pages, 2019. 
[17] T. Kostecki and A. J. S. Spearing, "Influence of backfill on coal pillar strength and floor bearing capacity in weak floor conditions in the Illinois Basin," International Journal of Rock Mechanics and Mining Sciences, vol. 76, pp. 55-67, 2015.

[18] E. Yilmaz, T. Belem, M. Benzaazoua, A. Kesimal, B. Ercikdi, and F. Cihangir, "Use of high-density paste backfill for safe disposal of copper/zinc mine tailings," Mineral Resources Management, vol. 27, no. 3, pp. 81-94, 2011.

[19] P. Yang, L. Li, M. Aubertin, M. Brochu-Baekelmans, and S. Ouellet, "Stability analyses of waste rock barricades designed to retain paste backfill," International Journal of Geomechanics, vol. 17, no. 3, Article ID 04016079, 2016.

[20] F. Feng, D. Y. Li, X. B. Li, Z. P. Guo, S. F. Wang, and Y. Chen, "Novel underhand cut-and-fill stoping method and mechanical analysis of overlying backfill," International Journal of Geomechanics, vol. 17, no. 7, Article ID 04017004, 2017.

[21] C. Qi and A. Fourie, "Numerical investigation of the stress distribution in backfilled stopes considering creep behaviour of rock mass," Rock Mechanics and Rock Engineering, vol. 52, no. 9, pp. 3353-3371, 2019.

[22] Y. Ohnishi, T. Sasaki, T. Koyama, I. Hagiwara, S. Miki, and T. Shimauchi, "Recent insights into analytical precision and modelling of DDA and NMM for practical problems," Geomechanics and Geoengineering, vol. 9, no. 2, pp. 97-112, 2014.

[23] Y. Zhu, Y. Li, Z. Hao, L. Luo, J. Luo, and L. Wang, "An analytical solution for the frost heaving force and displacement of a noncircular tunnel," Computers and Geotechnics, vol. 133, Article ID 104022, 2021.

[24] P. P. Nomikos, A. I. Sofianos, and C. E. Tsoutrelis, "Structural response of vertically multi-jointed roof rock beams," International Journal of Rock Mechanics and Mining Sciences, vol. 39, no. 1, pp. 79-94, 2002.

[25] C. Qiao, Y.-H. Guo, and C.-H. Li, "Study on rock burst prediction of deep buried tunnel based on cusp catastrophe theory," Geotechnical \& Geological Engineering, vol. 39, no. 2, pp. 1101-1115, 2021.

[26] Q. Jiang, G. Su, X.-T. Feng, G. Chen, M.-Z. Zhang, and C. Liu, "Excavation optimization and stability analysis for large underground caverns under high geostress: a case study of the Chinese Laxiwa project," Rock Mechanics and Rock Engineering, vol. 52, no. 3, pp. 895-915, 2019.

[27] R. Habibi, H. Moomivand, M. Ahmadi, and A. Asgari, "Stability analysis of complex behavior of salt cavern subjected to cyclic loading by laboratory measurement and numerical modeling using LOCAS (case study: nasrabad gas storage salt cavern)," Environmental Earth Sciences, vol. 80, no. 8, pp. 1-21, 2021.

[28] W. Yang, Y. Jiang, X. Gu, Z. Wang, Y. Shang, and W. Zeng, "Deformation mechanism and mechanical behavior of tunnel within contact zone: a case study," Bulletin of Engineering Geology and the Environment, vol. 80, no. 7, pp. 5657-5673, 2021.

[29] H. S. Mitri, R. Hughes, and Y. Zhang, "New rock stress factor for the stability graph method," International Journal of Rock Mechanics and Mining Sciences, vol. 48, no. 1, pp. 141-145, 2011.

[30] L. Yang, W. Xu, E. Yilmaz, Q. Wang, and J. Qiu, “A combined experimental and numerical study on the triaxial and dynamic compression behavior of cemented tailings backfill," Engineering Structures, vol. 219, Article ID 110957, 2020.

[31] E. Yilmaz, T. Belem, M. Benzaazoua, and B. Bussiere, "Assessment of the modified CUAPS apparatus to estimate in situ properties of cemented paste backfill," Geotechnical Testing Journal, vol. 33, no. 5, pp. 351-362, 2010.
[32] J. A. Vallejos, A. Delonca, and E. Perez, "Three-dimensional effect of stresses in open stope mine design," International Journal of Mining, Reclamation and Environment, vol. 32, no. 5, pp. 355-374, 2018.

[33] H. Jia, K. Guan, W. Zhu, H. Liu, and X. Liu, "Modification of rock stress factor in the stability graph method: a case study at the Alhada Lead-Zinc Mine in Inner Mongolia, China," Bulletin of Engineering Geology and the Environment, vol. 79, no. 6, pp. 3257-3269, 2020.

[34] Y. Potvin, "Empirical Open Stope Design in Canada," Doctoral Thesis, The University of British Columbia, Vancouver, Canada, 1988.

[35] F. T. Suorineni, "A critical review of the stability graph method for open stope design," in Proceedings of the MassMin 2012, pp. 10-14, Canadian Institute of Mining, Metallurgy and Petroleum, Sudbury, Canada, June 2012.

[36] F. T. Suorineni, "The stability graph after three decades in use: experiences and the way forward," International Journal of Mining, Reclamation and Environment, vol. 24, no. 4, pp. 307-339, 2010.

[37] Q. Liu, J. Liu, Y. Pan, X. Kong, and K. Hong, "A case study of TBM performance prediction using a Chinese rock mass classification system - h," Tunnelling and Underground Space Technology, vol. 65, pp. 140-154, 2017.

[38] N. Barton, "Some new Q-value correlations to assist in site characterisation and tunnel design," International Journal of Rock Mechanics and Mining Sciences, vol. 39, no. 2, pp. 185-216, 2002.

[39] M. Benzaazoua, T. Belem, and E. Yilmaz, "Novel lab tool for paste backfill," Canadian Mining Journal, vol. 127, no. 3, pp. 31-33, 2006. 